NBER WORKING PAPER SERIES

INTERNATIONAL LIQUIDITY AND MONETARY CONTROL

Jacob A. Frenkel

Working Paper No. 1118

NATIONAL BUREAU OF ECONOMIC RESEARCH

1050 Massachusetts Avenue

Cambridge MA 02138

May 1983

Paper presented at the Conference on International Money, Credit, and the SDR, International Monetary Fund, Washington, D.C., March 24-25, 1983. I am indebted to Craig $\mathrm{s}$. Hakkio, Lauren Feinstone and Helen Roberts for helpful comments and assistance and to the NSF Grant No. SES 78-11480-A01 for financial support. The research reported here is part of the NBER's research program in International Studies and in Economic Fluctuations. Any opinions expressed are those of the author and not those of the National Bureau of Economic Research. 


\section{International Liquidity and Monetary Control}

\section{ABSTRACT}

This paper deals with the relations among international liquidity, the exchange-rate regime and the effectiveness of monetary policy. The first part of the paper contains an empirical study of the demand for international reserves. It is shown that ( $i$ ) reserve holdings are a stable function of a limited number of economic variables, and (ii) the move to greater flexibility of exchange-rates has not changed drastically the patterns of reserves holdings. The empirical work deals with developed and developing countries and it allows for country-specific and time-specific factors as well as for dynamic adjustments. The second part of the paper deals with the more general issue of the constraints that the openness of the economy imposes on the effectiveness and proper conduct of monetary policy, as well as the dependence of these constraints on the exchangerate regime. In this context the roles of various exchange-market interventions are discussed. The analysis then explores alternative guidelines for monetary policy where it is argued that the conduct of policy can be improved by paying attention to the relation between exchange rates and interest rates. This relation is then used to interpret the recent evolution of interest rates. The paper concludes with a brief discussion of the role of the International Monetary Fund in the provision of 1iquidity. 


\section{INTRODUCTION}

This paper deals with the relations among international liquidity, the exchange-rate regime and the effectiveness of monetary policy. A typical argument for the choice of a flexible exchange rate regime is that such a regime provides countries with an added degree of freedom in the pursuit of macroeconomic policies. It is claimed that the added degree of freedom (or the added policy instrument) stems from the elimination of the legal commitment to peg the exchange rate and, thereby, it reduces the need for international reserves. In practice, however, one of the striking features of the international monetary system since the early 1970s has been the continued use of international reserves even though, legally, countries have been allowed to adopt a flexible exchange-rate regime. In spite of the change in the legal framework associated with the breakdown of the Bretton Woods agreement and formalized by the various amendments to the Articles of Agreements of the International Monetary Fund, countries have continued to use international reserves and have continued to intervene in the markets for foreign exchange. As a matter of fact, an observer of the patterns of countries' holdings and usages of international reserves would be hard pressed to detect a drastic change in the patterns of holdings of international reserves corresponding to the drastic changes in the legal commitment concerning exchange-market intervention. The change in economic behavior has been much less pronounced than expected on the basis of the theory concerning the benefits from the additional degree of freedom granted by the flexible exchange rate regime. 
Section I of this paper reports the results of an empirical study on the demand for international reserves during the period 1963-79. The main findings are that (i) countries' holdings of international reserves can be characterized with reasonable accuracy as a stable function of a limited number of economic variables, and (ii) the move to greater flexibility of exchange rates has not changed in a fundamental way the general patterns of reserve holdings. It follows therefore that, in contrast to earlier predictions, the questions concerning the provision of international reserves, and the discussions concerning the role of the International Monetary Fund in this context, are as relevant at the present time as they were during the Bretton Woods era.

Section II extends the scope of the discussion to the more general issue of the constraints that the openness of the economy imposes on the effectiveness and proper conduct of monetary policy, as well as the dependence of these constraints on the exchange rate regime. Section III discusses the question of whether the monetary authorities possess the capacity to sterilize the monetary implications of the balance of payments and the monetary implications of interventions in the foreign exchange market. This question is relevant for determining the extent to which monetary control can be regained in view of the international constraints. In this context the distinction is drawn between sterilized and non-sterilized interventions.

The discussion in Sections II and III deals with the influence that external constraints exert on the effectiveness of monetary control. 
Section IV turns the question on its head by examining ways by which monetary policy can influence the external constraint. Issues that are discussed in this context include the role that monetary policy should play in affecting exchange rates as well as the role that exchange rates should play in guiding monetary policy. Here it is argued that monetary policy can use information provided by the foreign exchange market in order to improve its conduct. Thus, it is argued, while the openness of the economy imposes severe constraints on the effectiveness of monetary controls, it also provides a potentially useful source of information.

Section $V$ concludes the paper with a brief discussion of the role of the IMF as well as some proposals for institutional reform. 


\section{INTERNATIONAL RESERVES}

This section analyzes the determinants and the patterns of reserve holdings under alternative exchange-rate regimes. It contains an empirical analysis of the demand for international reserves in which cross-sectional estimates of the demand for reserves by developed and less-developed countries as well as estimates of pooled time series and cross sections are presented. In this context, the differences in behavior patterns of developed and lessdeveloped countries are analyzed. The analysis then turns to the empirical question of timing, of when the system moved from pegged to floating rates. The interest in this question stems from the belief that the timing of changes in economic behavior need not correspond to, or be associated with, the timing of changes in legal commitments. One of the conclusions emerging from the analysis is that the extent of the change in economic behavior (as far as the holdings of international reserves is concerned) has not been as large as might have been expected.

The Determinants of the Demand for International Reserves

Earlier studies of the demand for reserves considered the variability of international receipts and payments as an important argument in the demand function (e.g., Kenen and Yudin, 1965; Clower and Lipsey, 1968; Archibald and Richmond, 1971). In addition, it has been suggested that the demand function also depends on the propensity to import (e.g., Heller, 1966; Kelly, 1970; Clark, 1970a; Flanders, 1971; Frenkel, 1974a, 1974b, 1978; Hipple, 1974; Iyoha, 1976). These other studies have recently been surveyed by Grubel (1971), Williamson (1973), Claassen (1974), Cohen (1975) and Cumby (1982), and the general issue of the role of and needs for international liquidity were discussed in IMF (1970). 
The choice of a variability measure as an argument in the demand function stems directly from the role of international reserves in serving as a buffer stock accomodating fluctuations in external transactions.

Consequently, it has generally been expected that the demand for reserves Is positively associated with the extent of these fluctuations.

The rationale for the use of the propensity to import as an argument is more involved. It stems from an application of the Keynesian model of the foreign trade multiplier. According to that model, an external disequilibrium that is induced by a decline in export earnings could be corrected by a decline in output proportional to the multiplier. The cost of output adjustment could be saved if the monetary authorities are able to run down their stock of international reserves, thereby enabling them to finance the external deficit. Since the foreign-trade multiplier (and thus the required output dampening due to the fall in exports) is inversely related to the marginal propensity to import, this approach argues that the cost of not having reserves, and hence the demand for reserves, is inversely related to the marginal propensity to import (see references op cit.). In the absence of data on the marginal propensity to import, earlier empirical studies have replaced it by the ratio of imports to income, i.e., by the average propensity (typically referred to as the degree of "openness" of the economy). The coefficient of the average propensity to import frequently appeared with the "wrong" (positive) sign when used to estimate the demand for reserves. Thus, Hipple (1974) and Iyoha (1976) argue that the average import propensity should not be interpreted as a proxy for the cost of output adjustment but rather as a proxy for "openness," thus measuring the extent to which the economy is vulnerable to external disruptions. Accordingly, the positive coefficient on 
the average import propensity reflects the fact that the demand for reserves is a positive function of external vulnerability.

Using an adjustment mechanism which emphasizes the role of relative prices, price level and demand for money, it was previously shown (Frenkel, 1974a) that under certain assumptions, the demand for reserves was expected to be associated positively with the average propensity to import. This association was shown to be consistent with data for the period 1963-1967 for both Developed and Less-Developed Countries (Frenkel, 1974b). A simplified derivation of the association between reserve holdings and the propensity to import is presented in Frenkel (1978) where it is shown that the relationship between these two variables is, in general, not clear cut, although, under some assumptions this relationship is expected to be positive.

In what follows, cross-sectional estimates of the demand for international reserves are presented. Included, in addition to the above mentioned variables, is a scaling variable as one of the determinants of the demand. ${ }^{1}$

Cross-Sectional Estimates of the Demand for International Reserves

The empirical analysis includes data from 22 Developed Countries (DC's) for the period 1963-79 and 32 Less-Developed Countries (IDC's) for the period 1963-77. Appendices I and II contain the list of countries and definitions of variables used in the analysis. The classification of countries as Developed and Less-Developed is based on that of the IMF. The choice of countries and the period of analysis were determined by the availability of continuous series of data. ${ }^{2}$ As indicated above, the demand function was assumed to depend on three variables: (i) a measure of variability of international receipts and payments denoted by $\sigma$; the value of $\sigma$ for each year was estimated by 
computing the standard deviation over the previous 14 years of the trendadjusted annual changes of the level of reserves; ${ }^{3}$ (ii) a scaling variable measuring the size of international transactions represented by the level of GNP, Y; in the few cases where this was not available, it was replaced by Gross Domestic Product,: (GDP), and (1ii) the average propensity to 1mport, $\mathrm{m}=\mathrm{IM} / \mathrm{Y}$, where $\mathrm{IM}$ denotes imports.

The functional form of the demand function was assumed to be:

$$
\ln R_{t}=\alpha_{0}+\alpha_{1} \quad \ln \sigma_{t}+\alpha_{2} \ln Y_{t}+\alpha_{3} \ln m_{t}+u_{t}
$$

where $u_{t}$ denotes an error term. Finally, and in contrast with most of the earlier empirical formulations, the demand for reserves is specified in real terms. Thus, as indicated in Appendix II, $R_{t}$ denotes the real value of international reserves.

Tables 1 and 2 present for each year the cross-sectional ordinaryleast-squares estimates of the demand for reserves by Developed and LessDeveloped Countries. In all cases the coefficients have the expected positive sign and in most cases these coefficients are statistically signiflcant at the 95 percent confidence level.

In summary it should be noted that the overall fit of the regressions reported in Tables 1 and 2 (as measured by the coefficients of determination $\mathrm{R}^{2}$ ) is very satisfactory. This point is noteworthy since these results pertain to cross-sectional estimates. Of special interest is the good fit of the cross-sectional regressions for the last few years reported in Tables 1 and $2 .^{4}$ During the latter years of the sample period, the international monetary system moved towards a greater. flexibility of exchange rates. This move was expected to result in different as well as in less stable estimates 
TABLE 1

International Reserves: Cross-Section Equations Estimation Method: OLS; Developed Countries ( $\mathrm{N}=22)$

(standard errors in parentheses)

\begin{tabular}{|c|c|c|c|c|c|c|}
\hline Year & Constant & $\ln \sigma$ & $\ln Y$ & $\ln \mathrm{m}$ & $R^{2}$ & $\begin{array}{l}\text { Standard } \\
\text { Error }\end{array}$ \\
\hline 1963 & $\begin{array}{c}4.081 \\
(0.678)\end{array}$ & $\begin{array}{c}0.625 \\
(0.198)\end{array}$ & $\begin{array}{c}1.063 \\
(0.086)\end{array}$ & $\begin{array}{c}1.398 \\
(0.295)\end{array}$ & 0.90 & 0.434 \\
\hline 1964 & $\begin{array}{c}4.240 \\
(0.775)\end{array}$ & $\begin{array}{c}0.607 \\
(0.236)\end{array}$ & $\begin{array}{c}1.012 \\
(0.091)\end{array}$ & $\begin{array}{c}1.348 \\
(0.293)\end{array}$ & 0.88 & 0.477 \\
\hline 1965 & $\begin{array}{c}4.476 \\
(0.876)\end{array}$ & $\begin{array}{c}0.492 \\
(0.270)\end{array}$ & $\begin{array}{c}1.061 \\
(0.103)\end{array}$ & $\begin{array}{c}1.373 \\
(0.333)\end{array}$ & 0.86 & 0.530 \\
\hline 1966 & $\begin{array}{c}4.415 \\
(0.925)\end{array}$ & $\begin{array}{c}0.592 \\
(0.284)\end{array}$ & $\begin{array}{c}1.100 \\
(0.107)\end{array}$ & $\begin{array}{c}1.634 \\
(0.349)\end{array}$ & 0.86 & 0.542 \\
\hline 1967 & $\begin{array}{c}4.201 \\
(0.918)\end{array}$ & $\begin{array}{c}0.659 \\
(0.282)\end{array}$ & $\begin{array}{c}1.147 \\
(0.109)\end{array}$ & $\begin{array}{c}1.755 \\
(0.350)\end{array}$ & 0.86 & 0.557 \\
\hline 1968 & $\begin{array}{c}4.184 \\
(1.151)\end{array}$ & $\begin{array}{c}0.580 \\
(0.325)\end{array}$ & $\begin{array}{c}1.151 \\
(0.125)\end{array}$ & $\begin{array}{c}1.602 \\
(0.365)\end{array}$ & 0.85 & 0.588 \\
\hline 1969 & $\begin{array}{c}4.277 \\
(0.970)\end{array}$ & $\begin{array}{c}0.519 \\
(0.270)\end{array}$ & $\begin{array}{c}0.995 \\
(0.109)\end{array}$ & $\begin{array}{c}1.266 \\
(0.319)\end{array}$ & 0.84 & 0.553 \\
\hline 1970 & $\begin{array}{c}3.985 \\
(0.838)\end{array}$ & $\begin{array}{c}0.574 \\
(0.249)\end{array}$ & $\begin{array}{c}1.016 \\
(0.105)\end{array}$ & $\begin{array}{c}1.196 \\
(0.324)\end{array}$ & 0.85 & 0.536 \\
\hline 1971 & $\begin{array}{c}4.378 \\
(0.785)\end{array}$ & $\begin{array}{c}0.356 \\
(0.243)\end{array}$ & $\begin{array}{c}1.017 \\
(0.105)\end{array}$ & $\begin{array}{c}0.779 \\
(0.340)\end{array}$ & 0.86 & 0.540 \\
\hline 1972 & $\begin{array}{c}3.572 \\
(0.629)\end{array}$ & $\begin{array}{c}0.742 \\
(0.220)\end{array}$ & $\begin{array}{c}0.943 \\
(0.079)\end{array}$ & $\begin{array}{c}1.014 \\
(0.325)\end{array}$ & 0.90 & 0.425 \\
\hline 1973 & $\begin{array}{c}3.862 \\
(0.675)\end{array}$ & $\begin{array}{c}0.716 \\
(0.275)\end{array}$ & $\begin{array}{c}0.972 \\
(0.093)\end{array}$ & $\begin{array}{c}1.272 \\
(0.446)\end{array}$ & 0.88 & 0.472 \\
\hline 1974 & $\begin{array}{c}3.083 \\
(0.788)\end{array}$ & $\begin{array}{c}0.872 \\
(0.325)\end{array}$ & $\begin{array}{c}1.061 \\
(0.099)\end{array}$ & $\begin{array}{c}1.581 \\
(0.481)\end{array}$ & 0.88 & 0.526 \\
\hline 1975 & $\begin{array}{c}3.311 \\
(0.941)\end{array}$ & $\begin{array}{c}0.704 \\
.(0.349)\end{array}$ & $\begin{array}{c}1.190 \\
(0.135)\end{array}$ & $\begin{array}{c}1.750 \\
(0.601)\end{array}$ & 0.85 & 0.603 \\
\hline 1976 & $\begin{array}{c}3.260 \\
(0.915)\end{array}$ & $\begin{array}{c}0.816 \\
(0.338)\end{array}$ & $\begin{array}{c}1.139 \\
(0.122)\end{array}$ & $\begin{array}{c}1.923 \\
(0.564)\end{array}$ & 0.85 & 0.582 \\
\hline 1977 & $\begin{array}{c}3.225 \\
(0.608)\end{array}$ & $\begin{array}{c}0.825 \\
(0.216)\end{array}$ & $\begin{array}{c}1.275 \\
(0.082)\end{array}$ & $\begin{array}{c}2.222 \\
(0.340)\end{array}$ & 0.93 & 0.411 \\
\hline 1978 & $\begin{array}{c}4.382 \\
(0.751)\end{array}$ & $\begin{array}{c}0.306 \\
(0.257)\end{array}$ & $\begin{array}{c}1.113 \\
(0.101)\end{array}$ & $\begin{array}{c}1.256 \\
(0.377)\end{array}$ & 0.88 & 0.552 \\
\hline 1979 & $\begin{array}{c}3.681 \\
(0.670)\end{array}$ & $\begin{array}{c}0.564 \\
(0.222)\end{array}$ & $\begin{array}{c}1.136 \\
(0.085)\end{array}$ & $\begin{array}{c}1.585 \\
(0.298)\end{array}$ & 0.91 & 0.486 \\
\hline
\end{tabular}


TABLE 2

Internationa1 Reserves: Cross-Section Equations Estimation Method: OLS; Less-developed Countries ( $N=32)$ (standard errors in parentheses)

\begin{tabular}{|c|c|c|c|c|c|c|}
\hline Year & Constant & $\ln \sigma$ & $\ln Y$ & $\ln m$ & $R^{2}$ & $\begin{array}{l}\text { Standard } \\
\text { Error }\end{array}$ \\
\hline 1963 & $\begin{array}{c}5.724 \\
(0.663)\end{array}$ & $\begin{array}{c}0.297 \\
(0.174)\end{array}$ & $\begin{array}{c}1.244 \\
(0.108)\end{array}$ & $\begin{array}{c}1.895 \\
(0.294)\end{array}$ & 0.84 & 0.523 \\
\hline 1964 & $\begin{array}{c}5.641 \\
(0.705)\end{array}$ & $\begin{array}{c}0.241 \\
(0.190)\end{array}$ & $\begin{array}{c}1.196 \\
(0.116)\end{array}$ & $\begin{array}{c}1.732 \\
(0.299)\end{array}$ & 0.80 & 0.553 \\
\hline 1965 & $\begin{array}{c}5.529 \\
(0.635)\end{array}$ & $\begin{array}{c}0.189 \\
(0.179)\end{array}$ & $\begin{array}{l}1.125 \\
(0.116)\end{array}$ & $\begin{array}{c}1.412 \\
(0.293)\end{array}$ & 0.79 & 0.539 \\
\hline 1966 & $\begin{array}{c}4.866 \\
(0.710)\end{array}$ & $\begin{array}{c}0.380 \\
(0.201)\end{array}$ & $\begin{array}{c}1.114 \\
(0.139)\end{array}$ & $\begin{array}{c}1.509 \\
(0.359)\end{array}$ & 0.73 & 0.627 \\
\hline 1967 & $\begin{array}{c}4.108 \\
(0.830)\end{array}$ & $\begin{array}{c}0.586 \\
(0.223)\end{array}$ & $\begin{array}{c}1.253 \\
(0.174)\end{array}$ & $\begin{array}{c}1.697 \\
(0.431)\end{array}$ & 0.70 & 0.753 \\
\hline 1968 & $\begin{array}{c}4.518 \\
(0.737)\end{array}$ & $\begin{array}{c}0.425 \\
(0.193)\end{array}$ & $\begin{array}{c}1.215 \\
(0.147)\end{array}$ & $\begin{array}{c}1.526 \\
(0.352)\end{array}$ & 0.74 & 0.684 \\
\hline 1969 & $\begin{array}{c}4.531 \\
(0.748)\end{array}$ & $\begin{array}{c}0.297 \\
(0.204)\end{array}$ & $\begin{array}{c}1.206 \\
(0.135)\end{array}$ & $\begin{array}{c}1.244 \\
(0.317)\end{array}$ & 0.77 & 0.655 \\
\hline 1970 & $\begin{array}{c}4.212 \\
(0.796)\end{array}$ & $\begin{array}{c}0.293 \\
(0.222)\end{array}$ & $\begin{array}{l}1.207 \\
(0.141)\end{array}$ & $\begin{array}{l}1.077 \\
(0.327)\end{array}$ & 0.76 & 0.719 \\
\hline 1971 & $\begin{array}{c}4.810 \\
(0.826)\end{array}$ & $\begin{array}{c}0.240 \\
(0.235)\end{array}$ & $\begin{array}{c}1.237 \\
(0.134)\end{array}$ & $\begin{array}{c}1.312 \\
(0.312)\end{array}$ & 0.77 & 0.684 \\
\hline 1972 & $\begin{array}{c}4.981 \\
(0.713)\end{array}$ & $\begin{array}{c}0.269 \\
(0.203)\end{array}$ & $\begin{array}{c}1.232 \\
(0.109)\end{array}$ & $\begin{array}{c}1.330 \\
(0.249)\end{array}$ & 0.83 & 0.592 \\
\hline 1973 & $\begin{array}{c}3.747 \\
(0.614)\end{array}$ & $\begin{array}{c}0.549 \\
(0.187)\end{array}$ & $\begin{array}{c}1.191 \\
(0.093)\end{array}$ & $\begin{array}{l}1.148 \\
(0.214)\end{array}$ & 0.86 & 0.537 \\
\hline 1974 & $\begin{array}{c}2.872 \\
(0.774)\end{array}$ & $\begin{array}{c}0.703 \\
(0.257)\end{array}$ & $\begin{array}{c}1.103 \\
(0.118)\end{array}$ & $\begin{array}{c}0.995 \\
(0.280)\end{array}$ & 0.78 & 0.700 \\
\hline 1975 & $\begin{array}{c}3.328 \\
(0.665)\end{array}$ & $\begin{array}{c}0.603 \\
(0.205)\end{array}$ & $\begin{array}{c}1.070 \\
(0.125)\end{array}$ & $\begin{array}{c}1.142 \\
(0.281)\end{array}$ & 0.75 & 0.737 \\
\hline 1976 & $\begin{array}{c}3.623 \\
(0.753)\end{array}$ & $\begin{array}{c}0.462 \\
(0.224)\end{array}$ & $\begin{array}{c}1.158 \\
(0.134)\end{array}$ & $\begin{array}{c}1.007 \\
(0.293)\end{array}$ & 0.74 & 0.807 \\
\hline 1977 & $\begin{array}{c}3.383 \\
(0.803)\end{array}$ & $\begin{array}{c}0.569 \\
(0.255)\end{array}$ & $\begin{array}{l}1.141 \\
(0.133)\end{array}$ & $\begin{array}{c}1.072 \\
(0.296)\end{array}$ & 0.76 & 0.759 \\
\hline
\end{tabular}


of the parameters of the demand for reserves. Since, as will be shown below, the cross-sectional estimates seem to have remained stable (at least during the periods 1963-72 and 1973-79), more efficient estimates may be obtained by pooling the time series with cross sections.

Pooled Time-Series and Cross-Sections:

Pegged Versus Floating Exchange Rates

In order to examine the effect of the move to a regime of flexible exchange rates, the sample was divided into two periods: the pegged exchange rate period (1963-72) and the flexible exchange rate period (1973-79). A formal justification for this division is provided subsequently.

To the extent that the coefficients of the cross-sectional equations remained stable within each of the periods 1963-72 and 1973-79, one may obtain more efficient estimates by pooling the time-series with the cross-sections. Table 3 contains the ordinary-1east-squares estimates of the pooled regression for both periods. In all cases the coefficients are positive and significant at the 95 percent confidence level.

I turn now to a comparison of the regression coefficients between Developed and Less-Developed countries during the two periods. The first method used for this comparison was the dummy variables method as outlined by Gujarti (1970). According to this method, each and every coefficient was allowed to differ between Developed and Less-Developed Countries by including dummy variables pertaining to data for Developed Countries. The estimated coefficients of the dummy variables (not reported here) reveal that for the first period the coefficients of the constant term and of income are significantly lower for Developed Countries while the coefficient of the variability measure is higher. For the latter period, however, the behavior of the two groups with respect to international reserves is much more similar. 
TABLE 3

International Reserves: Pooled Time Series-Cross Section

Estimation Method: OLS (standard errors in parentheses)

\begin{tabular}{|c|c|c|c|c|c|c|c|}
\hline Period & Group $^{1}$ & Constant & $\ln \sigma$ & $\ln \mathrm{Y}$ & $\ln \mathrm{m}$ & $\mathrm{R}^{2}$ & $\begin{array}{l}\text { Standard } \\
\text { Error }\end{array}$ \\
\hline \multicolumn{8}{|l|}{$1963-72$} \\
\hline & DCs & $\begin{array}{c}4.108 \\
(0.249)\end{array}$ & $\begin{array}{c}0.594 \\
(0.074)\end{array}$ & $\begin{array}{c}1.059 \\
(0.039)\end{array}$ & $\begin{array}{c}1.353 \\
(0.100)\end{array}$ & 0.85 & 0.504 \\
\hline & LDCs & $\begin{array}{c}4.848 \\
(0.225)\end{array}$ & $\begin{array}{c}0.317 \\
(0.062)\end{array}$ & $\begin{array}{c}1.191 \\
(0.040)\end{array}$ & $\begin{array}{c}1.428 \\
(0.099)\end{array}$ & 0.76 & 0.623 \\
\hline \multicolumn{8}{|l|}{$1973-77$} \\
\hline & DCs & $\begin{array}{c}3.381 \\
(0.361)\end{array}$ & $\begin{array}{c}0.750 \\
(0.137)\end{array}$ & $\begin{array}{c}1.106 \\
(0.049)\end{array}$ & $\begin{array}{c}1.619 \\
(0.219)\end{array}$ & 0.85 & 0.543 \\
\hline & LDCs & $\begin{array}{c}3.346 \\
(0.310)\end{array}$ & $\begin{array}{c}0.575 \\
(0.096)\end{array}$ & $\begin{array}{c}1.114 \\
(0.518)\end{array}$ & $\begin{array}{c}1.020 \\
(0.117)\end{array}$ & 0.77 & 0.694 \\
\hline \multicolumn{8}{|l|}{$1973-79$} \\
\hline & DCs & $\begin{array}{c}3.615 \\
(0.290)\end{array}$ & $\begin{array}{c}0.636 \\
(0.105)\end{array}$ & $\begin{array}{c}1.105 \\
(0.038)\end{array}$ & $\begin{array}{c}1.520 \\
(0.160)\end{array}$ & 0.86 & 0.532 \\
\hline
\end{tabular}

1 DCs: developed countries. LDCs: 1ess-developed countries. 
The dummy variables method focuses on comparisons between individual coefficients. The second method that was employed in the comparison between Developed and Less-Developed Countries was that of the Chow-test, and also this test leads to the conclusion that the difference between the behavior of Developed and Less-Developed Countries concerning the holdings of international reserves had diminished significantly during the second period. It is of interest to explore in greater detail the patterns of the move to the floating rates regime, as are implied by the characteristics of reserve holdings.

International Reserves and the Change in Regime

The analysis in the previous sections made a distinction between the periods 1963-72 and 1973-79. The presumption was that the evolution of the international monetary system from pegged exchange rates to floating exchange rates might have resulted in a structural change in the demand for international reserves. In the present section I examine formally the timing and extent of the structural change following the method proposed by Quandt $(1958,1960) .^{5}$

Consider a situation in which a structural change occurred at year t* within the period $1, \ldots, T$ and assume that the demand for reserves corresponding to the two regimes (before and after $t^{*}$ ) can be characterized by two distinct regression equations like (2) - (3)

$$
\begin{array}{ll}
y_{i t}=x_{i t}^{\prime} \beta_{1}+u_{1 i t}, & t \leq t^{*} \\
y_{i t}=x_{i t}^{\prime} \beta_{2}+u_{2 i t}, & t>t^{*}
\end{array}
$$


where $u_{i t}$ and $u_{2 i t}$ are the error terms that are assumed to be distributed as $N\left(0 ; \sigma_{1}^{2}\right)$ and $N\left(0, \sigma_{2}^{2}\right), \beta_{1}$ and $\beta_{2}$ are the vectors of the regression coefficients corresponding to the two regimes, and where $i=1, \ldots, N$ denotes the countries (for the Developed Countries $N=22$ and for the LDC's $N=32$ ). The analysis of the timing of the structural change amounts to searching for the value of $t *$. Quandt's method of estimating $t *$ involves the following: first, a maximization of the likelihood function (4) conditional on t*:

$$
\begin{aligned}
L(y \mid t *)=\left(\frac{1}{2 \pi}\right)^{N T / 2} \sigma_{1}-N \sigma_{\sigma_{2}}^{-N(T-t *)} \exp \left\{-\frac{1}{2 \sigma_{1}^{2}} \sum_{t=1}^{t *} \sum_{i=1}^{N}\left(y_{i t}-x_{i t}^{\prime} \beta_{1}\right)^{2}-\right. \\
\left.-\frac{1}{2 \sigma_{2}^{2}} \sum_{t=t *+1}^{T} \sum_{i=1}^{N}\left(y_{i t}-x_{i t}^{\prime} \beta_{2}\right)^{2}\right\}
\end{aligned}
$$

(where $\mathrm{N}$ denotes the number of countries and $\mathrm{T}$ denotes the number of years), and second, determination of the breakpoint $t^{*}$ as the valie which yields the highest maximum likelihood $\mathrm{L}\left(\mathrm{y} \mid \mathrm{t}^{*}\right)$. The application of this procedure to determining the breakpoint in the demand for reserves, yields 1972 as the estimate for t* for Less-Developed Countries. For the Developed Countries the breakpoint is less clear and the choice between 1972 and 1973 as the relevant breakpoint is somewhat arbitrary.

Based on these results, 1972 is used as the estimate of the break point for both the Developed and the Less Developed Countries, implying that from the viewpoint of reserve holdings, 1972 marks the end of the first subperiod. The validity of this assumption was tested by applying the likelihood-ratio test to the null hypothesis that no switch took place between 1972 and 1973 . The likelihood ratio statistic is

$$
\phi=\hat{\sigma}_{1}^{N} \hat{t}_{2}^{*} N\left(T-\hat{\sigma}^{*}\right) / \hat{\sigma}^{N T}
$$


where $\hat{\sigma}^{\mathrm{NT}}$ is the estimated standard deviation of the residuals from the single regression estimated over the entire period 1963-79 for Developed Countries and 1963-77 for LDC's.

According to the null hypothesis, $-2 \ln \phi$ is distributed $x^{2}$ with degrees of freedom corresponding to the number of constraints. The null hypothesis was rejected for both groups of countries at the 99 percent confidence level. ${ }^{6}$ The practical implication is that for the purpose of estimation, data from the period 1963-72 should not be pooled with those from the subsequent period and that the structural change occurred by the end of 1972 .

In addition to the above test one may also use a Chow-test to test for the equality of the regression coefficients between the two periods. The resulting values of the F-statistics relevant for testing the null hypothesis were well above the critical values at the 99 percent confidence level for both groups of countries. Thus, the Chow-test as well leads to the rejection of the null hypothesis. The overall inference is that the system had changed by the end of 1972. It is this conclusion which provides the rationale for the pattern of the intertemporal pooling that is employed in Table 3 . As may be seen from Table 3, the main changes in the estimated coefficients occurred in the constant term and in the coefficient of $\sigma$. For both groups of countries the constant term declined with the move to greater flexibility of exchange rates indicating that for given characteristics of the other economic variables, the holding of reserves (in real terms) declined during the second period. Likewise, both groups of countries revealed higher sensitivity to the variability measure during the second period. In general it is relevant to note that the results concerning the patterns of reserve holdings are consistent with the findings in Suss (1976) and in Heller and Khan (1978). Finally it is important 
to emphasize that the above discussion associated the structural change with the change in the exchange rate regime; it could of course reflect other (not necessarily unrelated) phenomena which occurred in the early $1970^{\prime}$ s like the oil crisis and the commodity price boom.

\section{Country-Specific and Time-Specific Factors}

The estimates of the demand for international reserves in Table 3 combined cross-section and time-series data using ordinary-least-squares (OLS) estimation. Implementing this estimation method requires that the residuals in equation ( 1 ) be uncorrelated among countries at a point in time as well as over time. This assumption, however, may not be fully justified in view of earlier findings (e.g., Frenkel 1974b, 1978) that there are countries whose reserve holdings exhibit persistent positive residuals (Switzerland and Austria) and there are countries whose holdings exhibit persistent negative residuals (the U.K. and New Zealand). This phenomenon suggests that there might be some country-specific and possibly also some time-specific factors which determine the demand for international reserves. These country-specific factors may be the result of historical, political and social influences that are not captured by the conventional set of arguments in the reserves function. Although it may not be possible to explain these factors, it is important to take account of their influence on the error structure. An incorporation of these factors in the estimation procedure should increase the efficiency of the estimated parameters, and the improved estimates should be useful in assessing the 'adequacy' of international liquidity and its distribution among countries.

In what follows the possibility that the residuals from the estimated demand for reserves contain country-specific factors and time-specific factors is allowed for by applying the error-components model (see Balestra and Nerlove $(1966)) \cdot 7$ 
In order to emphasize the possibility of country-specific factors, equation (I) is written below as (5) without suppressing the country index $i$.

$$
\ln R_{i t}=\beta_{0}+\beta_{1} \ln \sigma_{i t}+\beta_{2} \ln Y_{i t}+\beta_{3} \ln m_{i t}+u_{i t}
$$

where as before $R_{i t}$ denotes the real value of reserves held by country $i$ at time $t, \sigma_{\text {it }}$ denotes the variability measure for country $i$ at period $t$, $\mathrm{Y}_{\text {it }}$ designates the scale variable and the openness of the economy is measured by the average propensity to import $m_{i t}$. The subsequent analysis focuses on the 22 developed countries.

The error term $u_{i t}$ is assumed to be composed of three independent parts (i) $\mu_{i t}$, the country-specific factor, which is assumed to be invariant with time, (ii) $\lambda_{t}$, the time-specific factor which is assumed to be common to all countries in the cross-section and (iii) $\varepsilon_{i t}$, a serially uncorrelated identically distributed random variable. Formally, the error-components model can be specified as

$$
u_{i t}=\mu_{i}+\lambda_{t}+\varepsilon_{i t} \quad(i=1,2, \ldots, N ; t=1,2, \ldots, T)
$$

where $\mu_{i}, \lambda_{t}$ and $\varepsilon_{i t}$ are independent normal variables each with zero mean such that

$$
\begin{aligned}
& E\left(\mu_{i^{\prime} j^{\prime}}\right)=\left\{\begin{array}{l}
\sigma^{2}, i=i^{\prime} . . \\
0, i \neq i^{\prime}
\end{array}\right. \\
& E\left(\lambda_{t^{\prime} t^{\prime}}\right)=\left\{\begin{array}{l}
\sigma_{\lambda}^{2}, t=t^{\prime} \\
0, t \neq t^{\prime}
\end{array}\right. \\
& E\left(\varepsilon_{\left.i t^{\prime} \varepsilon_{i^{\prime} t^{\prime}}\right)}=\left\{\begin{array}{l}
\sigma_{\varepsilon^{\prime}}^{2} i=i^{\prime} \text { and } t=t^{\prime} \\
0 \text { otherwise }
\end{array}\right.\right.
\end{aligned}
$$


The specification of the errors implies that $u_{i t}$ is homoskedastic and that its variance is the sum of the variances of the three components:

$$
\sigma_{u}^{2}=\sigma_{\mu}^{2}+\sigma_{\lambda}^{2}+\sigma_{\varepsilon}^{2}
$$

The assumption that the errors are correlated requires the application of a generalized-least-squares (GLS) estimation method. Table 4 reports the GLS estimates of equation (5) for the pegged and the flexible exchange-rate regimes. A comparison of the parameter estimates in Table 4 with the corresponding estimates in Table 3 reveals the extent of the differences. In comparison with the OLS estimation method the GLS estimation method yields lower estimates of the coefficients of the measures of variability and openness. The GLS estimates also reveal that the variance of the error $\sigma_{u}^{2}$ is mainly due to the variance of the country-specific factors, $\sigma_{\mu}^{2}$, which underlie the cross-sectional regressions. In contrast, the variance of the time-specific component, $\sigma_{\lambda}^{2}$, which underlie the variations in the time series, plays a relatively minor role.

\section{Forecasts}

The previous results demonstrated that as a statistical matter the system underwent a structural change by the end of 1972 , and that allowance for country-specific factors alters the numerical value of the estimates of the various parameters. The relevant question is, what is the operational relevance of these findings? Do they imply that the move to the second regime rendered the estimates that were based on data from the first regime obsolete? This question is of some practical importance since quite frequently a relatively long period of time elapses before sufficiently new data are accumulated, and before additional research efforts yield new estimates. Likewise, does the fact that GLS estimates differ from the corre- 
TABLE 4

International Reserves: Pooled Time Serles-Cross Section

Estimation Method: GLS, Developed Countries

\begin{tabular}{|c|c|c|c|c|c|c|c|}
\hline Period & Constant & $\ln \sigma$ & $\ln Y$ & $\ln m$ & $\sigma_{\mu}^{2}$ & $\sigma_{\lambda}^{2}$ & $\sigma_{\varepsilon}^{2}$ \\
\hline $1963-72$ & $\begin{array}{c}4.196 \\
(0.412)\end{array}$ & $\begin{array}{c}0.315 \\
(0.083)\end{array}$ & $\begin{array}{c}0.953 \\
(0.078)\end{array}$ & $\begin{array}{c}0.582 \\
(0.187)\end{array}$ & 0.215 & 0.016 & 0.063 \\
\hline $1973-79$ & $\begin{array}{c}3.748 \\
(0.461)\end{array}$ & $\begin{array}{c}0.432 \\
(0.119)\end{array}$ & $\begin{array}{c}1.031 \\
(0.078)\end{array}$ & $\begin{array}{c}0.925 \\
(0.218)\end{array}$ & 0.196 & 0.018 & 0.086 \\
\hline
\end{tabular}


sponding OLS estimates imply that the latter are useless? To gain perspective into this question, the accuracy of forecasts of reserve holdings during the second regime based on parameter estimates from the first regime (1963-72) are examined.

We start with computing the series of forecasts based on the GLS estimates of Table 4. Since the time-invariant cross-sectional component of the errors plays a major role in accounting for the overall residual variance, one should be able to exploit this information in forecasting reserve holdings. For that purpose the country-specific factor $\hat{\mu}_{i}$ is first estimated as

$$
\hat{\mu}_{i}=\left(\sum_{t=1}^{T} \ln R_{i t}-\hat{\beta}_{G L S} \sum_{t=1}^{T} x_{i t}\right) / T
$$

where $\hat{B}_{\text {GLS }}$ denotes the vector of the GLS parameter estimates of equation (5) and where $x_{i t}$ denotes the vector of the right-hand-side variables of equation (5). Noting that the expected values of $\lambda_{t}$ and of $\varepsilon_{i t}$ are zero, it is assumed that

$$
\sum_{t=1}^{T} \lambda_{t}=\sum_{t=1}^{T} \varepsilon_{i t}=0 \quad \text { (for all } i \text { ) }
$$

and thus $\hat{\mu}_{i}$ (which was estimated from data corresponding to the period 1963-72) is treated as an estimate of the expected residual for the ith country for the second period. 8 The forecast of reserve holdings for country $i$ for the second period is therefore

$$
\hat{B}_{G L S} x_{i t}^{*}+\hat{\mu}_{i}
$$


where the superscript (*) indicates that the right-hand-side vector is based on data for 1973-79. This forecast utilizes the fact that the expected residuals $u_{i t}^{*}$ from the GLS regressions for the period 1973-79 are correlated with the residuals from the GLS regression for the period of 1963-72. In contrast, for the OLS regressions the corresponding best forecast is $\hat{\beta}_{\text {OLS }} x_{i t}^{*}$.

Table 5 contains the results of an evaluation of various forecasts of reserve holdings for the flexible exchange-rate regime on the basis of the information from the period of the pegged rate regime. These forecasts were derived from the parameter estimates of the OLS and the GLS regressions for 1963-1972 as reported in Tables 3 and 4. As may be seen, the correlation coefficients between the series of predictions and actual outcomes are quite high--ranging from 0.84 for the LDC's OLS estimates and 0.96 for the Developed Countries GLS estimates. Generally, the forecasts based on the GLS estimates are superior to those based on the OLS estimates. For example, comparing the quality of the forecasts for Developed Countries, the root mean square error and the mean error are 0.66 and -0.40 for the oLs forecast while the corresponding errors for the GLS forecast are only 0.46 and -0.23 respectively. 9

An additional procedure for the evaluation of the quality of the various forecasts follows Theil (1961). Consider a series of predictions $\mathrm{P}_{1}, \ldots, \mathrm{P}_{\mathrm{n}}$ and a series of the corresponding actual outcomes $A_{1}, \ldots, A_{n}$. Theil's inequality coefficient, which is bound between zero and 1 , is 


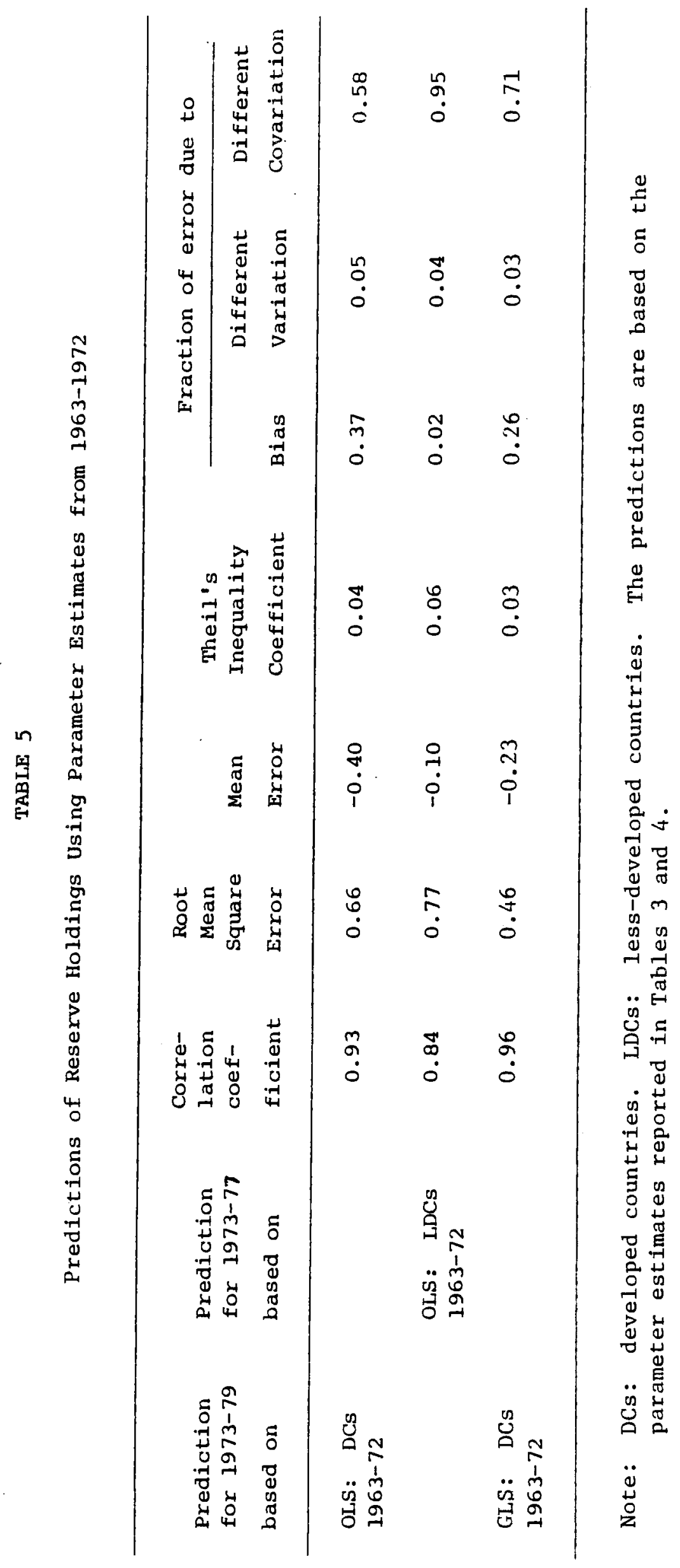




$$
U=\frac{\sqrt{\frac{1}{n} \sum\left(P_{i}-A_{i}\right)^{2}}}{\sqrt{\frac{1}{n} \sum P_{i}^{2}}+\sqrt{\frac{1}{n} \sum A_{i}^{2}}},
$$

according to which $U=0$ in the case of perfect forecast $\left(P_{i}=A_{i}\right.$ for all $\left.i\right)$, and $U=1$ in the case of extremely poor forecasting. The variance of the forecast errors (the square root of which is the numerator of $U$ ) can be decomposed as

$$
\frac{1}{n} \sum\left(P_{i}-A_{i}\right)^{2}=(\bar{P}-\bar{A})^{2}+\left(s_{P}-s_{A}\right)^{2}+2(1-r) s_{P} s_{A}
$$

where $\bar{P}, \bar{A}, s_{P}$ and $s_{A}$ are the means and the standard deviations of the series of predictions and actual outcomes respectively; and where $r$ is their correlation coefficient. Denoting the denominator of $U$ by $D$, Theil defines $\mathrm{U}_{\mathrm{M}} \equiv(\overline{\mathrm{P}}-\overline{\mathrm{A}}) / \mathrm{D}, \mathrm{U}_{\mathrm{S}} \equiv\left(\mathrm{s}_{\mathrm{P}}-\mathrm{s}_{\mathrm{A}}\right) / \mathrm{D}$ and $\mathrm{U}_{\mathrm{C}} \equiv \sqrt{2(1-\mathrm{r}) \mathrm{s}_{\mathrm{P}} \mathrm{s}_{\mathrm{A}}} / \mathrm{D}$ and thus

$$
\mathrm{U}_{\mathrm{M}}^{2}+\mathrm{U}_{\mathrm{S}}^{2}+\mathrm{U}_{\mathrm{C}}^{2}=\mathrm{U}^{2}
$$

where the three terms on the left-hand side of equation (10) are referred to as the partial coefficients of inequality due to unequal central tendency, to unequal variation and to imperfect covariation, respectively. Normalizing these terms by $U^{2}$ yields

$$
U^{M}+U^{S}+U^{C}=1
$$

where $\mathrm{U}^{\mathrm{M}} \equiv \mathrm{U}_{\mathrm{M}}^{2} / \mathrm{U}^{2}, \mathrm{U}^{\mathrm{S}} \equiv \mathrm{U}_{\mathrm{S}}^{2} / \mathrm{U}^{2}$ and $\mathrm{U}^{\mathrm{C}} \equiv \mathrm{U}_{\mathrm{C}}^{2} / \mathrm{U}^{2}$. 
In equation (11) $U^{M}, U^{S}$ and $U^{C}$ are the proportions of the inequality due to the above mentioned three different sources that are termed by Theil as the bias, the variance and the covariance proportions, respectively. It is clear that in the absence of perfect forecasting a desirable distribution of the inequality over the three sources is $U^{M}=0, U^{S}=0$ and $U^{C}=1$ since small proportions $U^{M}$ and $U^{S}$ indicate that systematic errors do not play a major role in forecast errors.

As may be in Table 5, Theil's inequality coefficients are very low, ranging from 0.03 to 0.06 . Furthermore, the forecast errors possess the "desirable" properties that most of the errors are not systematic, as indicated by the fact that their largest fraction is due to different covariation. Also in this respect it seems that the quality of the GLS forecasts for Developed Countries are more satisfactory than those of the corresponding OLS forecasts in that the fraction of the forecast error due to bias and to different variation is lower than the GLS forecasts. Based on the magnitudes of the sources of the error, it seems that the quality of the forecasts is somewhat better for the Less-Developed Countries than for the Developed Countries. Consistent with the previous results, it seems that the behavior of the developed countries with respect to reserve holdings underwent a more drastic structural change than that of the Less-Developed Countries. In fact, on the basis of the relatively good forecasts, it seems that the structural change, while statistically significant, was not of sufficient magnitude to make the old estimates completely obsolete.

The relative stability of the patterns of reserve holdings suggests the following interpretation: during the pegged rate regime the rate was adjust- 
able rather than fixed and during the so-called floating rate regime the rate has been managed rather than free. Economic behavior seems to be more stable than legal arrangements. Central banks have revealed that their choice is for neither of the extreme exchange rate systems, but have rather, preferred to have the intermediate system of managed floating. Since managing the float requires international reserves, one would expect to find a relatively stable demand for reserves, which might not differ greatly from the demand estimated for the adjustable peg regime.

The Dynamics of Adjustment

The analysis up to this point assumes that countries were "on" their long-run demand function. The following discussion draws a distinction between short-run and long run demand function and examines the speed of adjustment of reserves to their long-run desired value. While crosssectioned studies have identified the key variables which determine the holdings of international reserves, some work on the dynamics of adjustment found that the speed at which actual reserves adjust towards target reserves is very slow and is of ten not significantly different from zero (see for example Clark [1970b] and Iyoha [1976]). ${ }^{10}$ If correct, then these findings cast some doubt on the usefulness of the cross-sectional studies for the analysis of the adequacy of international reserves since evidence of a stable long-run demand function is of little value if it cannot be used to show that discrepancies between actual and desired stocks are eliminated over time. 
In Bilson and Frenkel (1979a, 1979b), however, it was shown that the earlier estimates of the speeds of adjustment were biased downwards and that in fact the speeds of adjustment for both the Developed Countries as well as the LDC's were reasonably high. Here, this framework is extended so as to allow the dynamic adjustment of international reserves to reflect both the Central Bank's excess demand for reserves and the public's excess demand for money. In that way the changes in the stock of international reserves reflect considerations which were emphasized in the literature on the demand for reserves as well as those which were emphasized in the literature on the monetary approach to the balance of payments. Equation (12) describes one general form of the reserve-adjustment equation:

$$
\Delta \ln R_{i t}=\alpha\left[\ln R_{i t}^{*}-\ln R_{i t-1}\right]+B\left[\ln M_{i t}^{*}-\ln M_{i t-1}\right]+u_{i t}
$$

where $R_{i t}^{*}$ and $M_{i t}^{*}$ denote respectively the desired levels of reserves and money for country $i$ at period $t$, and where $\alpha$ and $\beta$ denote the speeds of adjustment. 11

In order to estimate these speeds of adjustment it is necessary to obtain an estimate of the desired level of reserves and money as well as to specify the properties of the error term $u_{i t}$. The previous findings revealed that country-specific factors play important roles in governing countries' holdings of international reserves. Time-specific factors, on the other hand, have played only an insignificant role. Accordingly, it is assumed that the properties of the error term can be characterized by equation (6) with $\lambda_{t}$-- the time specific factor -- supressed to zero. Under the assumption that on average the holdings of international 
reserves and of real money balances equal their target level, these target levels can be estimated from equations (13)-(14).

$$
\begin{aligned}
& \ln R_{i .}=\beta_{0}+\beta_{1} \ln \sigma_{i .}+\beta_{2} \ln Y_{i .}+\beta_{3} \ln m_{i .}+\mu_{i} \\
& \ln \left(\frac{M}{P}\right)_{i .}=\gamma_{0}+\gamma_{1} \ln Y_{i .}-\gamma_{2} i_{i .}+\varepsilon_{1}
\end{aligned}
$$

where $R_{i}$. denotes the average level of reserves for country $i$ (where an average over time for country $i$ is denoted by ' $i . '$ ). Equation (14) is a conventional demand for money expressed as a function of income, $Y$, and the rate of interest, 1 . In equation (14) $M$ denotes the monetary base and $i$ the short-term nominal rate of interest. The choice of the monetary aggregate was made for two reasons. First, most countries do not pay interest on the monetary base whereas financial practices for broader monetary aggregates differ widely across countries. Second, the monetary base may be considered as the more appropriate aggregate for balance of payments analysis.

The first stage of the estimation procedure involves estimating equations (13)-(14) from the sample averages of the time-series-crosssection data base. The resulting estimates for the sample of the 22 developed countries over the two sub-periods are reported in Table 6 . The estimates of the parameters of the average demand for reserves are very similar to those reported in Table 3, and the estimates of the demand for money reveal a unit income elasticity and a negative interest elasticity. During the second period the interest elasticity declined (in absolute value) and its magnitude did not differ significantly from zero.

In the second stage of the estimation procedure the estimated 


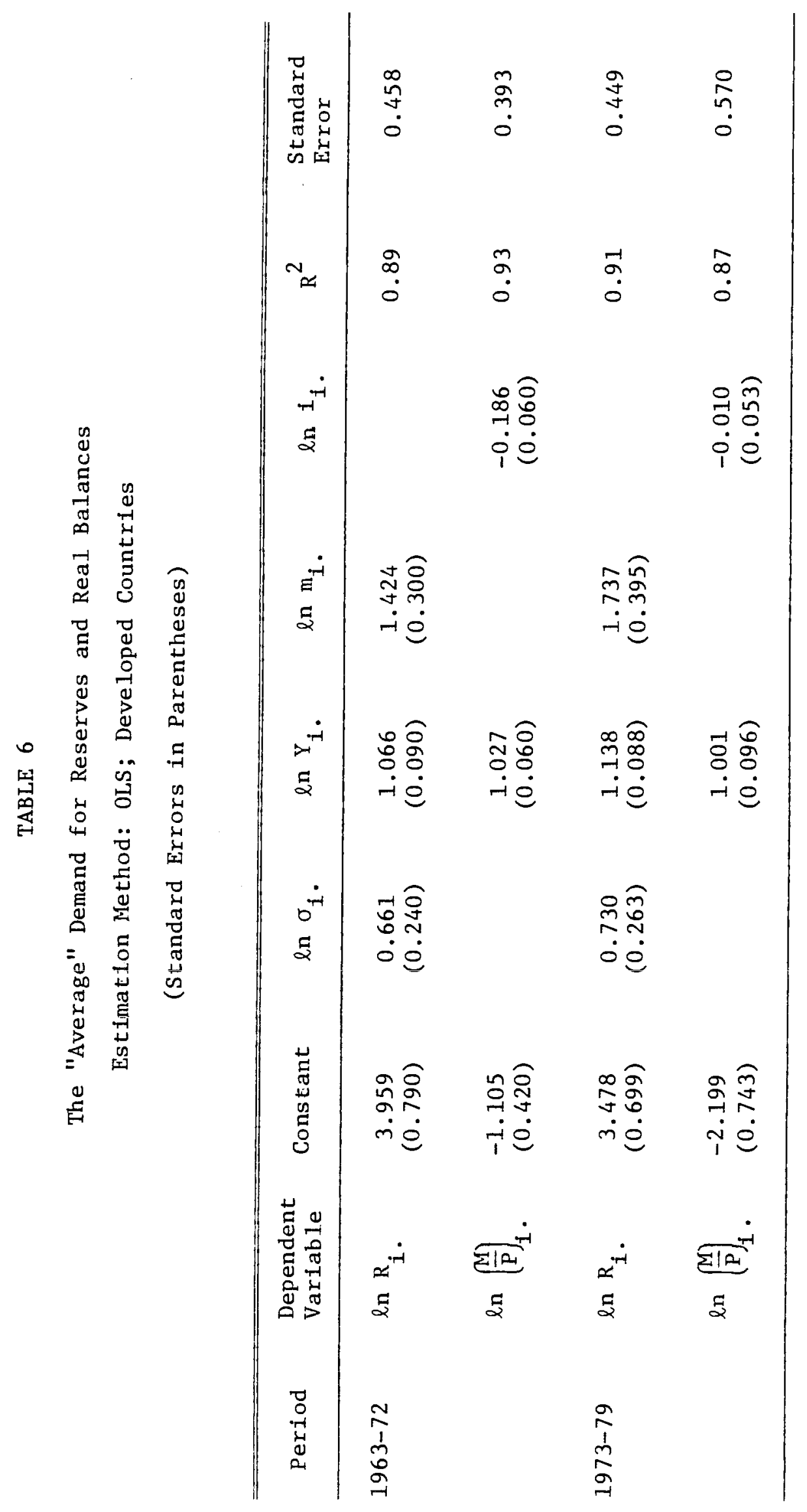


parameters of Table 6 are used to construct estimates of the target levels of reserves and money for country $i$ at period $t$. These magnitudes are estimated as

$$
\begin{aligned}
& \ln \mathrm{R}_{i t}^{*}=\hat{\beta}_{0}+\hat{\beta}_{1} \ln \sigma_{i t}+\hat{\beta}_{2} \ln Y_{i t}+\hat{\beta}_{3} \ln \mathrm{m}_{i t}+\hat{\mu}_{i} \\
& \ln \mathrm{M}_{i t}^{*}=\hat{\gamma}_{0}+\hat{\gamma}_{1} \ln Y_{i t}-\hat{\gamma}_{2} i_{i t}+\ln P_{i t}+\hat{\varepsilon}_{i}
\end{aligned}
$$

where the coefficients $\hat{\beta}_{i}(i=0, \ldots, 3)$ and $\hat{\gamma}_{i}(i=0, \ldots, 2)$ are the estimates of the corresponding coefficients in equations (13)-(14) as reported in Table 6 , and where the estimated values of the country-specific factors $\mu_{i}$ and $\varepsilon_{i}$ are defined as

$$
\begin{aligned}
& \hat{\mu}_{i}=\ln R_{i .}-\hat{\beta}_{0}-\hat{\beta}_{1} \ln \sigma_{i}-\hat{\beta}_{2} \ln Y_{i}-\hat{\beta}_{3} \ln m_{i} . \\
& \hat{\varepsilon}_{i}=\ln \left(\frac{M}{\bar{P}}\right)_{i}-\hat{\gamma}_{0}-\hat{\gamma}_{1} l_{n} Y_{i}-\hat{\gamma}_{2} i_{i} .
\end{aligned}
$$

Equations (17)-(18) define the country-specific factor $\mu_{i}$ and $\varepsilon_{i}$ as the systematic deviations of ith country's holdings of reseryes and cash. balances from the average holdings of the group of countries. It is noteworthy that in contrast with the previous studies, the definitions of the target levels of reserves and cash balances in equations (15)-(16), include the country-specific factors. The conventional approach to the analysis of the dynamics of adjustment has been to append the equilibrium specifications of the demands for reserves and for cash balances with a lagged dependent variable. The obvious problem with that approach arises from the existence of a country-specific factor. If this factor is not accounted for in the specification of the target levels of reserves and 
cash balances, the coefficients of the lagged dependent variables would be biased towards unity so that the estimated speed of adjustment would be biased downwards. As should be evident the two-stage procedure outlined here is not subject to this bias.

Using equations (15)-(16) to construct the target levels of reserves and cash balances the estimates of the speeds of adjustment in equation (12) are reported in Table 7 . The results support the specification in the adjustment equation (12). They demonstrate that the actual changes in reserves are influenced by both the excess demand for reserves by the Central Bank and by the private sector's excess demand for money. The speeds of adjustment are higher than those typically obtained by estimates of the coefficients on lagged dependent variables.

Finally, somewhat surprisingly, the estimated speeds of adjustments are higher during the flexible exchange-rate regime than during the peggedrate regime. As seen in Table 6 the adjustment coefficient to an excess demand for international reserves rose from 0.370 to 0.488 while the adjusted coefficient to an excess demand for money rose from 0.298 to 0.357 .

\section{An Overview}

This section contained an analysis of the role of international reserves under a regime of pegged exchange rates and under a regime of managed float. It presented evidence on the stability of the demand for reserves during the periods 1963-72 and 1973-79. It was shown that the demand for reserves by Developed Countries differs from that of Less-Developed Countries and that the system underwent a structural change by the end of 1972 . In view of the drastic 


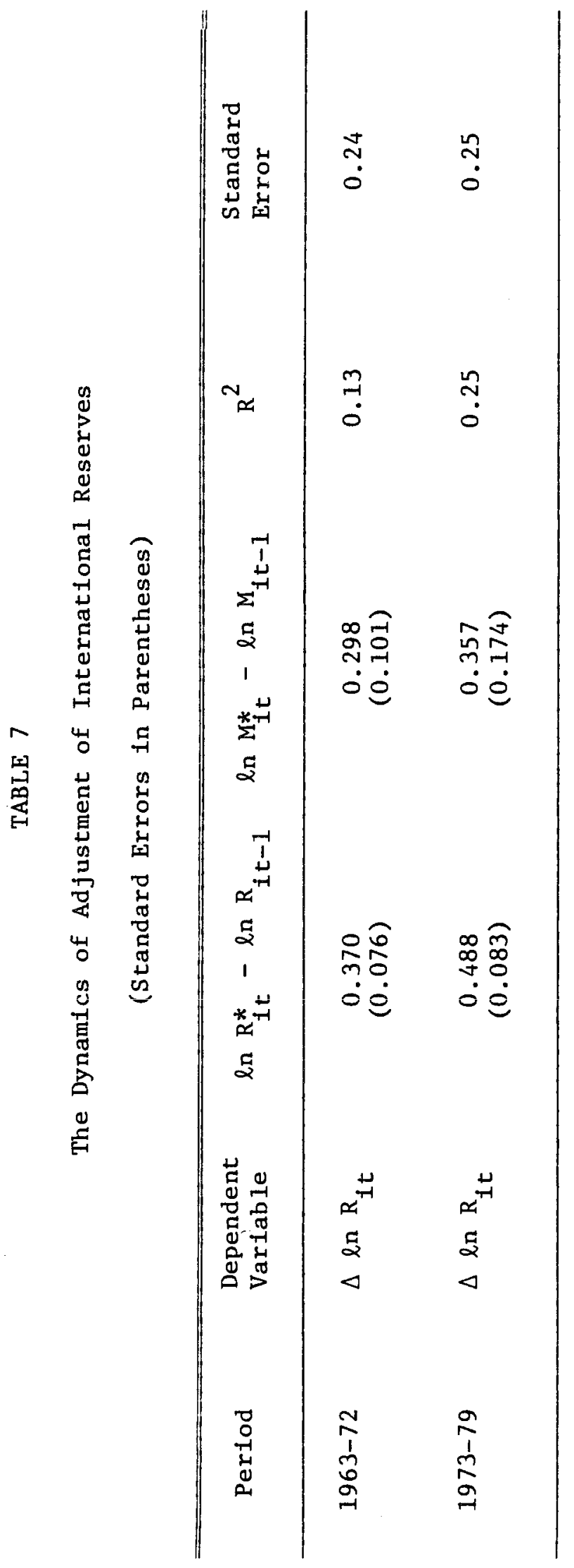


changes in the international monetary system, the extent of the structural change (in particular with reference to the behavior of developed countries) has not been as large as one might have expected. This finding led to the observation that economic behavior seems to be more stable than legal arrangements. The evidence indicates that countries have continued to hold and use international reserves, and they have chosen to manage their exchange rates rather than let them float freely. This suggests that the move to the floatingrate regime has not reduced significantly the need for international reserves, nor has it removed the need to establish clearly the means and mechanisms for the provision of such reserves. ${ }^{12}$ The section concluded with an analysis of the dynamics of adjustment to disequilibrium reserve holdings. It was shown that changes in the holdings of international reserves reflect both the excess demand for reserves on the part of the Central Bank, as well as excess demand for money on the part of the private sector. The estimated speeds of adjustment were shown to be larger than those reproted in earlier studies.

While much of the discussion in this section evolved around the details of econometric specifications and estimation procedures, the central implications should not be lost. The stability of the demand for international reserves and the adjustment mechanism that is triggered once reserve holdings differ from the desired level suggest that governments have chosen to include internationalreserves target in the list of targets which guides and constrains the conduct of macroeconomic policies. The evidence suggests that the move to greater flexibility of exchange rates has not removed this constraint in any material way. The next section deals with the more general questions of the constraints that the openness of the economy imposes on the effectiveness of policies and the impact of the exchange-rate regime on the effectiveness of these constraints. 


\section{THE INTERNATIONAL CONSTRAINTS ON MONETARY CONTROL}

The discussion in the previous section ended with the conclusion that the evidence on the stability of the demand for international reserves across exchange-rate regimes indicates that attempts to attain desired reserve holdings have influenced and constrained the conduct of monetary policy. This section addresses the broader issue of the nature of the international constraints on monetary policy. 13

Generally, macroeconomic policies for open economies differ in fundamentally important ways from the corresponding policies for closed economies. The openness of the economy imposes constraints on the effectiveness and proper conduct of macroeconomlc policles in general, and of monetary control in particular. These constraints stem from the interdependence between the economy and the rest of the world. The open economy is linked to the rest of the world primarily through three key linkages: through international trade in goods and services; through international mobility of capital; and through international exchanges of national monies (see Frenkel and Mussa (1981) for a detailed analysis of the implications of these 11nkages for macro-economic policies.)

International trade links prices in different national economies. While the evidence on purchasing power parities reveals that this link is not rigid, it is evident that a country cannot choose its long-run trend in the inflation rate independent of the long-run courses of monetary policy and the exchange rate. This relation thus imposes a severe constraint on monetary policy. International mobility of capital links interest rates on financial assets. In addition, by permitting countries to finance current-account im- 
balances, it provides for a channel through which macroeconomic disturbances are transmitted internationally. The international mobility of capital limits the power of monetary policy. Under a fixed exchange-rate regime, a monetary expansion in excess of money demand is likely to have only a limited success in sustaining the change in the nominal money stock. Any temporary reduction in the domestic rate of interest will induce capital outflow and a loss of foreign exchange reserves, and any attempts to sterilize the monetary consequences of the loss of international reserves is unlikely to be viable in the long-run (more on this in Section (III). Under a flexible exchange rate regime the monetary authority regains control over the nominal money stock but the international mobility of capital still 1mposes a severe limitation on the ability of monetary policy to significantly affect the evolution of output and employment. A monetary expansion is likely to induce a rapid change in the exchange rate which leads to prompt adjustment of prices and wages.

The implication of capital mobility on the efficiency of policies is illustrated in Figure 1 [adapted from Frenkel and Rodriguez (1975)] which describes the effects of open market operations under fixed exchange rates. Consider a portfolio which is composed of real cash balances $M / P$ (where $P$ denotes the price level) and common stocks, $K$, and let the price of a security in terms of goods be $p_{k}$. It is assumed that the economy is small and fully integrated In world capital markets. As a result, since the foreign rate of interest is assumed to be given, the relative price of securities in terms of goods, $\mathrm{p}_{k}$, is also assumed to be fixed for the small open economy. The price level for the small open economy, $P$, is assumed to equal SP* where $S$ denotes the exchange rate and $P^{*}$ denotes the given foreign price. Thus, under fixed exchange rates the price level is given. The value of wealth, $W$, is thus

$$
W=\frac{M}{S P^{*}}+p_{k} K
$$




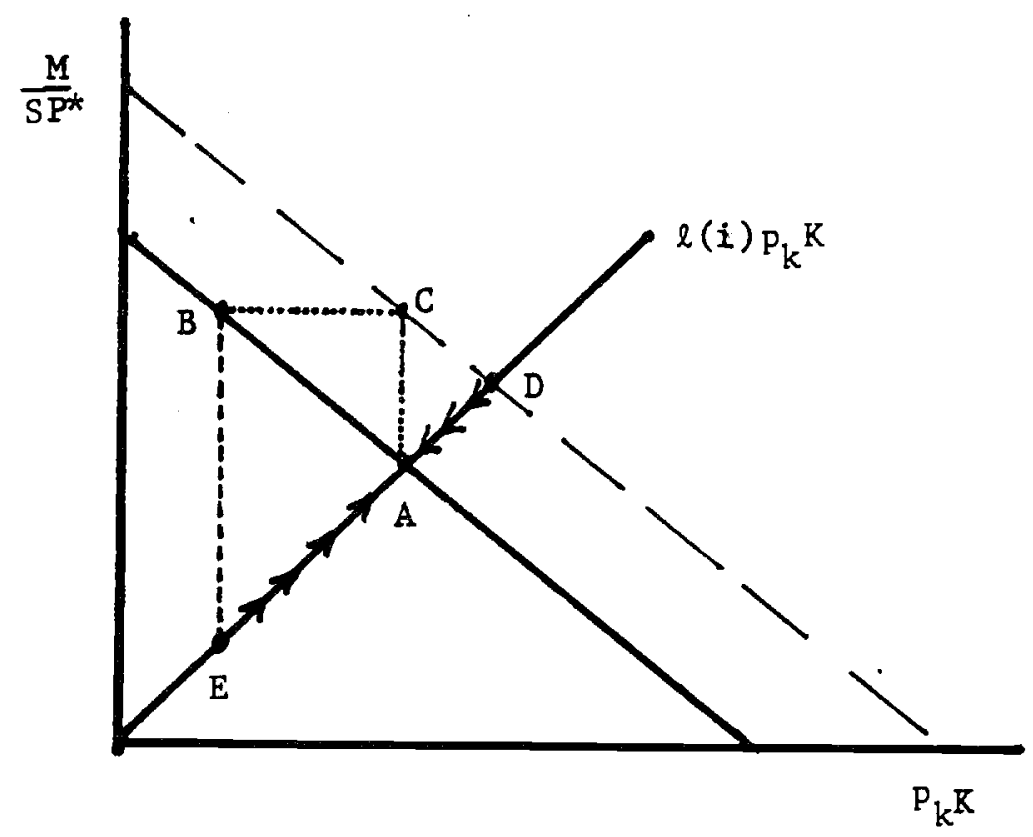

Figure 1: Portfolio Equilibrium and the Effects of Monetary Policy Under Fixed and Flexible Exchange-Rate Regimes. 
Suppose that the desired money/securities ratio depends negatively on the rate of interest as in equation (20).

$$
\frac{M}{S P *}=\ell(i) P_{k} K
$$

Port:folio equilibrium is described by point $A$ in Figure 1 . The negatively sloped schedule describes the wealth constraint and the positively sloped schedule describes the desired composition of assets given the rate of interest. An open market purchase moves the economy from point A to point B at which the money supply has risen and the holdings of securities by the private sector has fallen. Since at point $B$ the composition of the portfolio has been disturbed and since asset holders have access to world asset markets at the given rate of interest, they will restore portfolio equilibrium Instantaneously by exchanging the incteased stock of cash for foreign securities and thereby returning to point A. Thus, the fact that world capital markets are integrated and that open market operations are conducted in assets that are traded internationally at a given price, enables the private sector to nullify the actions of the monetary authority. In fact, in this case open market operations amount to an exchange of foreign exchange reserves for securities between the monetary authorities and foreign asset holders, and the entire process of adjustment is effected through the capital account of the balance of payments. The leverage of monetary policy can be somewhat enhanced if it operates in financial assets that are isolated from world capital markets since, in the short-run, the link between the rates of return on such assets with the world rates of interest is not as tight.

The same figure can be used for the analysis of a once and for all rise in the quantity of money that is brought about through an unanticipated transfer 
of cash balances which moves the economy from point $A$ to point $C$. The impact of this policy is to raise the value of assets and to raise the relative share of money in wealth. Portfolio composition equilibrium is restored by an immediate exchange of part of the increased monetary stock for equities as individuals move to point $D$. This exchange is effected through the capital account of the balance of payments. Since at $D$ the value of assets exceeds the equilibrium value at $A$, individuals will wish to run down their holdings of both equities and real cash balances by increasing expenditures relative to income. This part of the process will be gradual. The transition towards long-run equilibrium follows along the path from $D$ to $A$ and is characterized by a deficit in the current account, a surplus in the capital account and a deficit in the monetary account of the balance of payments.

Under flexible exchange rates, adjustments of real balances occur through changes in the exchange rate. Using the same diagram the effects of monetary policies are very different. An open market operation which brings the economy from point A to point B in Figure 1 cannot be nullified through the capital account since under flexible exchange rates money ceases to be an internationally traded commodity. Portfolio equilibrium is restored by an immediate rise in the exchange rate(i.e., a depreciation of the currency) which moves individuals from point $B$ to point E. As maybe seen, the percentage rise in the exchange rate exceeds the percentage rise in the money stock; this is the overshooting phenomenon. Since at $E$ the value of assets falls short of the long-run equilibrium value, individuals will wish to accummulate both equities and real balances by reducing expenditures relative to income. This part of the process will be gradual, and the transition from $\mathrm{E}$ to $\mathrm{A}$ is characterized by a surplus in the current account, a deficit in the capital account and an appreciation of the currency. 14

In contrast, when the rise in the quantity of money is brought about 
through a transfer which moves the economy from point $A$ to point $C$, the new equilibrium will be restored instantaneously through an equiproportionate depreciation of the currency which restores equilibrium at $A$.

The previous analysis of open market operations assumed implicitly that the returns on government holdings of securities are rebated to the private sector (in a lump sum fashion) but that the private sector does not capitalize the expected future flow of transfers. As a result the open market operations did not change the wealth position of individuals who moved from point $A$ to point B along the given wealth constraint. Under the alternative assumption that asset holders anticipate and capitalize the flow of transfers and treat them as any other marketable asset, they effectively conceive of the equities that are held by the government as their own. In that case the open market purchase only raises the supply of real cash balances and moves the economy from point A to point $C$. The effects of this policy are identical to the effects of the pure monetary expansion that is brought about through the governmental transfer.

The analysis of these two extreme cases implies that when international capital markets are highly integrated, the effectiveness of the constraints on monetary policy under fixed and flexible exchange-rate regimes depends on the degree to which the private sector capitalizes future streams of taxes and transfers as well as on the marketability of claims to such streams. ${ }^{15}$ When such claims are not fully perceived by individuals or by the capital market, the effects of open market operations are nullified rapidly under fixed exchange rates while the adjustment is gradual under flexible exchange rates. In constrast, when Individuals and capital markets do fully perceive these claims, the adjustment to open market operations is only gradual when the exchange rate is fixed while it is rapid when the exchange rate is flexible. These cases illustrate that the 
ranking of alternative exchange-rate regimes according to the speeds of adjustments to monetary policies is not unambiguous since it depends on the mechanism of monetary policy and on the public's perception of such policies.

The international exchange of national monies and the requirement of monetary equilibrium also impose a severe limitation on the effectiveness of monetary policy. As stated before, under a fixed exchange rate regime the authorities lose control over the nominal money stock while under a flexible rate regime the requirement of monetary equilibrium ensures that in the long-run changes in the nominal money stock lead to a proportionate change in all nominal prices and wages. Because of the rapid change in the exchange rate, the constraint on monetary policy that is Implied by the homogeneity postulate is likely to be manifested much more promptly in an open economy with flexible exchange rates than in a closed economy.

An additional consideration constraining the conduct of monetary policy follows from the dynamic linkage between current exchange rates and expectations of future exchange rates (see Mussa $(1976,1979)$ ). This dynamic 1inkage implies that the effect of monetary policy on the exchange rate, and thereby on other economic variables, depends on its effect on expectations concerning future policies. These expectations, in turn, are influenced by the past and by the current course of policy, and it is likely that the mere recognition of this dynamic linkage will influence the conduct of policy. For the government, being aware that the effectiveness of any particular policy measure depends on the way by which it influences the public's perception of the implications of the measure for the future conduct of policy, may become more constrained in employing the instrument of monetary policy.

In summary, the openness of the economy imposes constraints on monetary policy. These constraints are reflected in either a reduced ability to influence the instruments of monetary policy (like the nominal money supply under fixed 
exchange rates), or in a reduced ability to influence the targets of monetary policy (like the level of real output), or in an increased prudence in the use of monetary policy because of the potentially undesirable effects on expectations.

This discussion suggests that while the exchange-rate regime affects the nature of the constraints on policy, the constraints themselves stem from the openness of the economy. Furthermore, the choice of the exchange-rate regime does not alleviate the fundamental constraints even though it influences the manifestation of these constraints. With this perspective one may rationalize the findings (reported in Section I) that economic behavior with respect to reserve holdings has been more stable than what would have been predicted on the basis of the large changes in the legal arrangement. Policy makers seem to have recognized that a move to a regime of clean float which could have reduced the need for reserves, would have imposed significant costs associated with prompt translation of monetary changes into exchange rate changes as well as with large changes in real change rates. In view of these costs, policy makers have chosen not to enjoy fully the "degree of freedom" granted with the move to clean float.

The constraints on the conduct of monetary policy depend on the exchangerate regime. Therefore, the question of the country's choice of the optimal set of constraints on monetary policy can be answered in terms of the analysis of the choice of the optimal exchange rate regime. Such analysis reveals that the optimal exchange rate regime depends on the nature and the origin of shocks that affect the economy. Generally, the higher is the variance of real shocks which affect the supply of goods, the larger becomes the desirability of increased fixity of exchange rates. The rationale for the implication is that the balance of payments serves as a shock absorber which mitigates the effect of real shocks 
on consumption. The importance of this factor diminishes the larger is the degree of international capital mobility. On the other hand, the desirability of exchange-rate flexibility increases the larger are the variances of shocks to excess supply of money, to foreign prices and to deviations from purchasing power parities (see Frenkel and Aizenman [1982]).

\section{IIF. EXCHANGE-MARKET INTERVENTION}

The analysis of the international constraints on monetary policy is closely related to the analysis of the questions of whether the authorities can sterilize the monetary Implications of the balance of payments and the monetary implications of interventions in the market for foreign exchange. It is the need for occasional interventions in the market for foreign exchange that provided some of the rationale for the continued stable holdings of international reserves which were discussed in Section I. In this context, however, the difficulties in analysing that question start with definitions since exchange-market intervention means different things to different people (see Wallich [1982]). Some, especially in the United States, interpret foreign exchange intervention to mean sterilized intervention, that is, intervention which is not allowed to affect the monetary base and thus amounts to an exchange of domestic for foreign bonds. Others, especially in Europe, interpret foreign intervention to mean nonsterilized intervention. Thus, for the Europeans an intervention alters the course of monetary policy, while for the Americans it does not.

The distinction between the two concepts of intervention is fundamental and the exchange-rate effects of the two forms of intervention may be very different depending on the relative degree of substitution among assets. In principle, sterilized intervention may affect the exchange rate by portfoliobalance effects (see Allen and Kenen [1980], Branson [1979] and Henderson [1977]), 
and by signaling to the public the government's intentions concerning future policles, thereby changing expectations, (see Mussa [1981]). To the extent that sterilized intervention is effective in managing exchange rates, the constraint on the conduct of monetary polfcy would not be severe since the undesirable exchange rate effects of monetary policy could be offset by policles which alter appropriately the composition of assets. In practice, however, the evidence suggests that nonsterilized intervention which alters the monetary base has a strong effect on the exchange rate while an equivalent sterilized Intervention has very Ifttle effect (see obstefeld [1983]). These findings are relevant for both the theory of exchange rate determination and the practice of exchange rate and monetary policies. As to the theory, they shed doubts on the usefulness of the portfolfo-balance model. As to the practice, they demonstrate that the distinction between the two forms of intervention is critical if the authorities mean to intervene effectively, and that it may be inappropriate to assume that the open-economy constraints on monetary policy can be easily overcome by sterilization policies.

The preceding discussion defined interventions in terms of transactions involving spectfic pairs of assets. In evaluating these transactions it might be useful to explore the broader spectrum of possible policies. Figure 2 summarizes the various pattern of domestic and foreign monetary policies and foreign exchange interventions. These policles are divided into three groups as follows:

I : Domestic nonsterilized foreign exchange intervention

I*: Foreign nonsterilized foreign exchange intervention

II : Domestic monetary policy

II*: Forelgn monetary policy

III : Domestic sterilized foreign exchange intervention

III*: Foreign sterilized foreign exchange intervention 


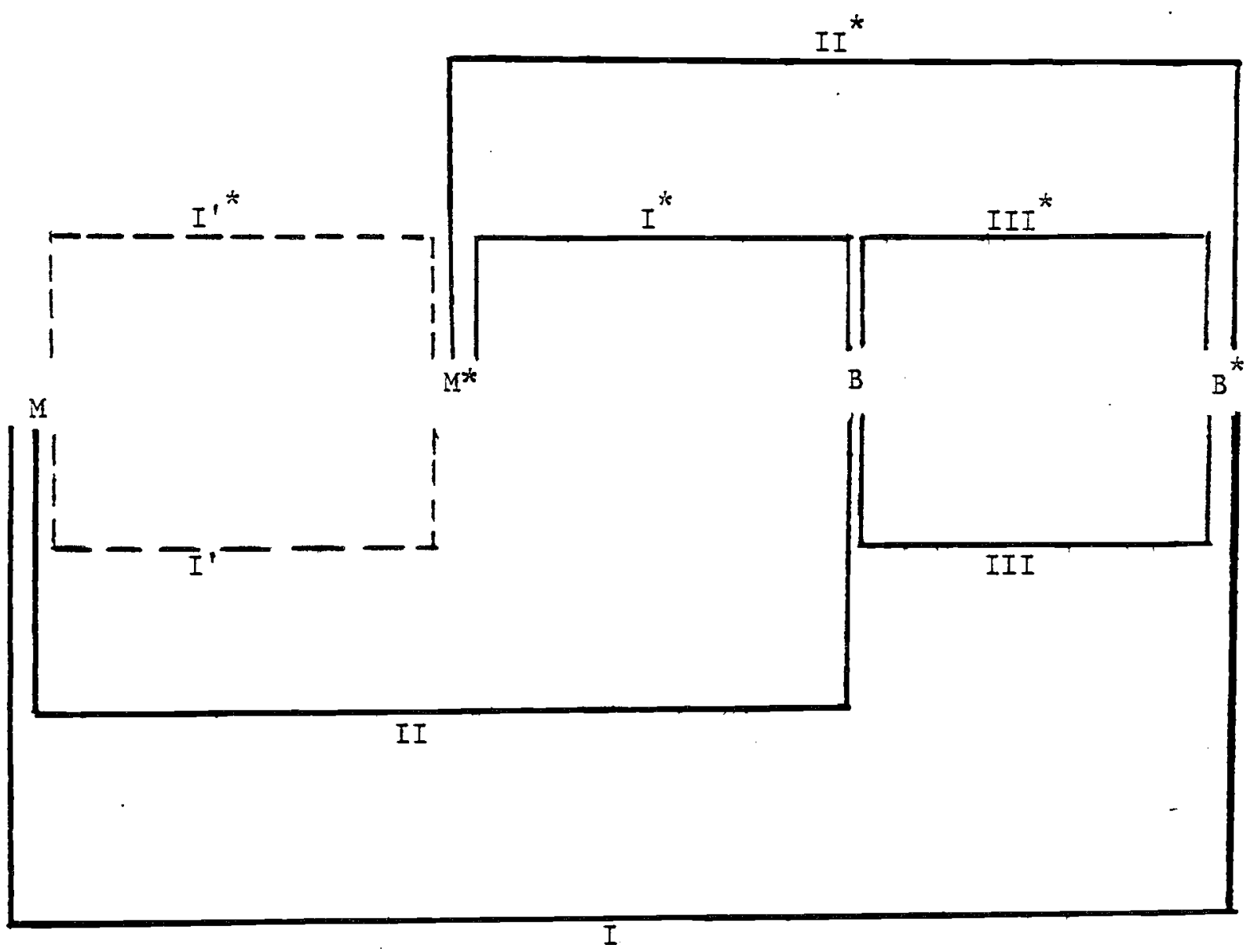

Figure 2: Patterns of domestic and foreign monetary policies and foreign exchange interventions. 
This classification is based on the types of assets that are being exchanged. Thus, when the authorities exchange domestic money ( $M$ ) for domestic bonds (B), the transaction is refered to as domestic monetary policy (as in II), while when the authorities exchange domestic bonds (B) for foreign bonds ( $B^{*}$ ), the transaction is being refered to as domestic sterilized foreign exchange intervention (as in III). Some have characterized pure foreign exchange intervention as an exchange of domestic money (M) for foreign money (M*) rather than the exchange of domestic money for foreign bonds. To complete the spectrum this type of exchange is indicated in Figure 2 by $I^{\prime}$ and $I^{\prime *}$, respectively.

This general classification highlights two principles. First, it shows that the differences between the various policies depend on the different characteristics of the various assets that are being exchanged. These different characteristics are at the foundation of the portfolio-balance model. Second, it shows that domestic and foreign variables enter symmetrically into the picture. Thus, for example, a given exchange between $M$ and $B^{*}$ can be effected through the policies of the home country or through a combination of policies of the foreign country. This symmetry suggests that there is room (and possibly a role) for international coordination of exchange rate policies. It also illustrates the "(n-I) problem" of the international monetary system: in a world of $n$ currencies there are $(n-1)$ exchange rates and only $(n-1)$ monetary authorities need to intervene in order to attain a set of exchange rates. To ensure consistency the international monetary system needs to specify the allocation of the remaining degree of freedom (see Mundel1 (1968)).

By and large the evidence on the effectiveness of sterilized intervention has been based on a comparison between patterns I and III within a single-country framework. It is possible that some of the findings emerging from the single- 
country studies may be modified once the foreign countries' behavior is taken into account. But, until presented with such evidence, it is reasonable to conclude that it is very difficult to conduct effectively independent monetary and exchange rate policies.

\section{GUIDELINES FOR MONETARY POLICY}

The analysis in Section II emphasized the constraints that are imposed on monetary control in the open economy. Under fixed exchange rates these constraints may be somewhat alleviated through sterilization policies, but the evidence sheds some doubt on the effectiveness of such attempts. As was also indicated, under flexible exchange rates the rapid changes in exchange rates also impose a constraint on the effectiveness of monetary policy in that they speed up the translation of monetary changes into changes in prices and wages. Furthermore, the recent volatility of exchange rates and the accompanying large divergence from purchasing power parities have been costly and have resulted in an increased perception that exchange-rate changes reduce the leverage of monetary policy. Attempts to alleviate some of these constraints have given rise to various proposals concerning rules for intervention in the foreignexchange market. Some of these proposals are variants of a PPP rule according to which the authorities are expected to intervene so as to ensure that the path of the exchange rate conforms to the path of the relative price levels. These proposals, if effective, amount to guidelines for the conduct of monetary policy.

There are at least four difficulties with a PPP rule. First, there are intrinsic differences between the characteristics of exchange rates and the price of national outputs. These differences, which result from the much stronger 
dependence of exchange rates (and other asset prices) on expectations, suggest that the fact that exchange rates have moved more than the price level is not sufficient evidence that exchange-rate volatility has been excessive.

Second, the prices of national outputs do not adjust fully to shocks in the short run and thus, intervention in the foreign exchange market to ensure purchasing power parity would be a mistake. When commodity prices are slow to adjust to current and expected economic conditions, it may be desirable to allow for "excessive" adjustment in some other prices.

Third, there are continuous changes in real economic conditions that require adjustment in the equilibrium relative prices of different national outputs. Under these circumstances what seem to be divergences from purchasing power parities may really reflect equilibrating changes.

Fourth, if there is short-run stickiness of prices of domestic goods in terms of national monies, then rapid exchange-rate adjustments, which are capable of changing the relative prices of different national outputs, are a desirable response to changing real economic conditions. An intervention rule which links changes in exchange rates rigidly to changes in domestic and foreign prices in accord with purchasing power parity ignores the occasional need for equilibrating changes in relative prices.

While it might be tempting to "solve" the problem of divergences from PPP by adopting a rigid PPP rule, this would be a mistaken policy course.

What should be the role of the exchange rate in the design of monetary policy? Generally, given that monetary and exchange-rate policies should not be viewed as two independent instruments, consideration of the external value of the currency should play a relatively minor role in the design of monetary policy. The major consideration that should guide the monetary authority is that of achieving price stability. 
While this prescription may seem to represent a revival of the "benign neglect" attitude the opposite is the case. In the past, one of the major arguments for the "benign neglect" attitude in the U.S. was that the U.S. economy was relatively closed and the foreign trade sector was relatively unimportant. The typical statistic which was used to justify this position was the low share of imports in GNP. This argument was inappropriate in the past and is even less appropriate under present circumstances. The U.S. has always been an open economy. The relevant measure of openness to international trade in goods and services is not the share of actual trade in GNP but rather the share of tradeable commodities in GNP (i.e., of potential trade) which is by far larger than that of actual trade. Furthermore, as stated in Section I, one of the main linkages of the U.S. to the world economy is operating through world capital markets with which the U.S. is clearly well integrated. The same principle applies to the measures of openness of most countries.

The prescription is based on the notions that the economy is open, that the external value of the currency is important, that the restoration of price stability is an important policy goal, and that policy which views the exchange rate as an independent target or, even worse, as an independent instrument, is likely to result in unstable prices. Furthermore, if monetary policy succeeds in achieving price stability, it might be useful to allow for fluctuations of the exchange rate which provide for a partial insulation from misguided foreign monetary policies.

Even when monetary policy is not guided by exchange rate targets it might attempt to offset disturbances arising from shifts in the demand for money. Such shifts in demand may be especially pronounced under a regime of flexible 
exchange rates. A policy which accommodates such demand shifts by offsetting supply shifts, would reduce the need for costly adjustments of exchange rates and national price levels. The difficulty with implementing this policy is in identifying when a shift in money demand has occurred. As is obvious, the nominal rate of interest is not a reliable indicator of money market conditions. The more relevant indicators are the components of the nominal rate of interest -the real rate of interest and the expected rate of inflation -- but these components are unobservable.

Here the exchange rate may be useful as an indicator for monetary policy especially when frequent changes in inflationary expectations make nominal interest rates an unreliable indicator of fluctuations in money demand. In order to determine the way in which exchange rates may serve as a useful indicator for the conduct of policy it is useful to start with an examination of the empirical record concerning the links between interest rates and exchange rates.

\section{Interest Rates and Exchange Rates}

One of the striking characteristics of the relation between the exchange rate and the interest differential has been the dramatic reversal of the relation which had taken place by the latter part of 1979 . The empirical record is illustrated by Figure 3 which shows the relation between the value of the dollar in terms of a trade-weighted basket of foreign currencies and the corresponding interest differential. As may be seen, there were generally two phases to the link between the value of the dollar and the interest differential. First, during the period 1973 through mid 1979, a higher interest rate in the U.S. (relative to foreign rates) was associated with a depreciation of 
FIGURE 3

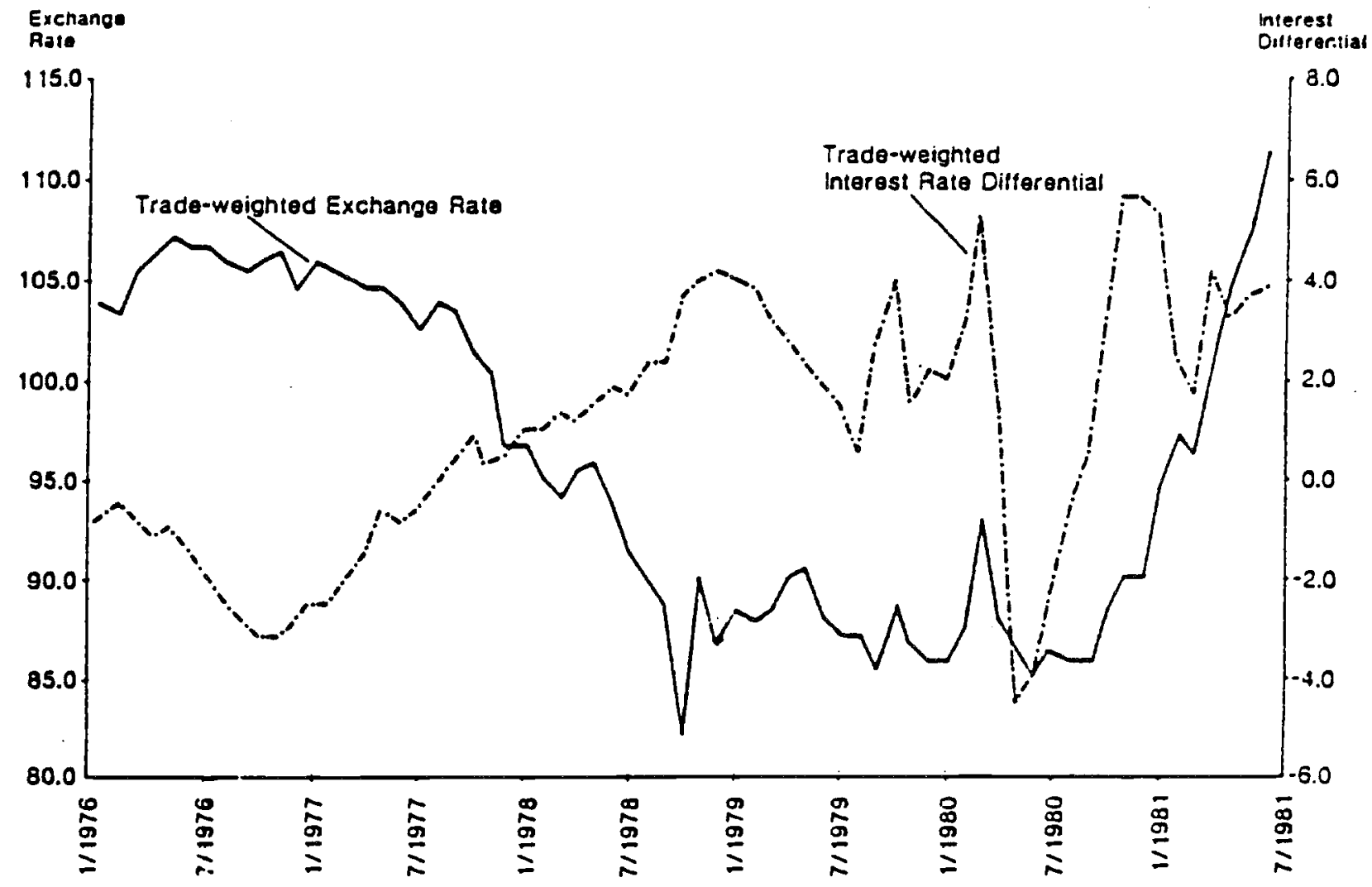

Figure 3: Foreign exchange value of the U.S. dollar and interest rate differential. The exchange rate is a trade-weighted average of the foreign currency value of the dollar, the interest differential is the U.S. 3-month comercial paper rate minus a trade-weighted foreign rate. The weights are from the Federal Reserve Bulletin, August 1978, page 700. 
the dollar and second, since about mid 1979, a higher interest differential has been associated with an appreciation of the dollar in terms of foreign exchange.

The same inference can be drawn from a comparison of the correlation coefficients between innovations (news) in the interest differentials and the various exchange rates. As shown in Table 8 , the correlation coefficients have changed sign since the latter part of 1979. This general pattern is independent of whether the various interest rate news are correlated with the level of the exchange rates or with the rate of change thereof. Nor does it depend on whether one uses the various measures of the exchange rates or the innovations (news) in these measures.

The reversal of the relation between the U.S. interest and the external value of the dollar which has taken place since mid 1979 , indicates that recently the prime cause for the fluctuations in U.S. interest rates has not been variations in inflationary expectations but rather variations in the real rate of interest. This distinction between the real rate of interest and inflationary expectations is the key factor in interpreting the empirical record.

The relation between the exchange rate, the real interest rate and the expected rate of inflation (relative to the corresponding foreign rates) can be derived from the following basic parity conditions. Equation (21) describes the interest parity condition that is implied by interest arbitrage:

$$
s_{t}=E_{t} s_{t+1}+i_{t}^{*}-i_{t}
$$

where $s_{t}$ denotes the logarithm of the exchange rate in period $t, E_{t}$ denotes the expectation operator (based on information avallable at period $t$ ) and thus, $E_{t} s_{t+1}$ denotes the expected (logarithm of) the exchange rate for period t+l based on the Information available at period $t ; i_{t}$ and $1_{t}^{*}$ denote the rates of interest on domestic and foreign securities that are identical in all respects except for the currency of denomination. 
TABLE 8

CORRELATIONS BETWEEN INNOVATIONS IN INTEREST DIFFERENTIALS AND EXCHANGE RATES Monthly Data: June 1973-July 1979 and August 1979-January 1982

\begin{tabular}{|c|c|c|c|c|c|}
\hline \multirow{2}{*}{\multicolumn{2}{|c|}{ Exchange Rates }} & \multicolumn{2}{|c|}{$\begin{array}{l}\text { Innovations in One-Month } \\
\text { Interest Differentials }\end{array}$} & \multicolumn{2}{|c|}{$\begin{array}{l}\text { Innovations in Twelve-Months } \\
\text { Interest Differentials }\end{array}$} \\
\hline & & $6 / 73-7 / 79$ & $8 / 79-1 / 82$ & $6 / 73-7 / 79$ & $8 / 79-1 / 82$ \\
\hline \multirow[t]{3}{*}{$\ln s$} & Dollar/Pound & .06 & -.21 & .08 & -.22 \\
\hline & Dollar/Franc & .14 & -.11 & .13 & -.16 \\
\hline & Dollar/DM & .07 & -.09 & .07 & -.14 \\
\hline \multicolumn{6}{|c|}{ Innovations in } \\
\hline $\ln \mathrm{s}$ & Dollar/Pound & .27 & -.65 & .37 & -.68 \\
\hline & Dollar/Franc & .30 & -.48 & .29 & -.70 \\
\hline & Dollar/DM & .25 & -.30 & .24 & -.45 \\
\hline \multirow[t]{3}{*}{$\Delta \ln S$} & Dollar/Pound & .29 & -.56 & .37 & -.59 \\
\hline & Dollar/Franc & .28 & -.46 & .26 & -.69 \\
\hline & Dollar/DM & .25 & -.31 & .24 & -.48 \\
\hline \multicolumn{6}{|c|}{ Innovations in } \\
\hline$\Delta \ln S$ & Dollar/Pound & .23 & -.65 & .34 & -.68 \\
\hline & Dollar/Franc & .31 & -.47 & .25 & -.69 \\
\hline & Dollar/DM & .24 & -.29 & .24 & -.44 \\
\hline
\end{tabular}

Note: Interest rates are the one-month and the twelve-months Euromarket rates. The expected interest rate differentials used in generating the innovations in the interest rate differential were computed from regressions of the interest differential on a constant, two-legged values of the differential, and the logarithm of the lagged forward exchange rate. The expected logarithm of the exchange rate used in generating the innovations in exchange rates was computed from a regression of the logarithm of the exchange rate on a constant, lagged values of the logarithms of the spot and the forward exchange rates and lagged interest rate differentials. The expected change in the logarithm of the exchange rate was computed from a regression of the percentage change in the exchange rate on lagged values of the percentage change of the exchange rate, lagged value of the forward premium and lagged value of the interest differential. 
The second parity condition is the Irving Fisher condition which expresses the nominal rate of interest $i$ as the sum of the real rate $I$ and the expected inflation. Equations (22) and (23) describe this condition for the domestic and the foreign rates of interest:

$$
\begin{aligned}
& i_{t}=r_{t}+E_{t}\left(p_{t+1}-p_{t}\right) \\
& i_{t}^{*}=r_{t}^{*}+E_{t}\left(p_{t+1}^{*}-p_{t}^{*}\right)
\end{aligned}
$$

where $p_{t}$ denotes the (logarithm of) the price level in period $t$ and where an asterisk denotes variables pertaining to the foreign country. Using equation (21), the interest parity for period $t-1$ is

$$
s_{t-1}=E_{t-1} s_{t}+1_{t-1}^{*}-i_{t-1}
$$

Subtracting equation (24) from equation (21) and using equations (22) and (23) yield

$$
\begin{aligned}
s_{t}= & s_{t-1}+\left[\left(p_{t}-p_{t-1}\right)-\left(p_{t}^{*}-p_{t-1}^{*}\right)\right]+\left[\left(r_{t}^{*}-r_{t-1}^{*}\right)-\left(I_{t}-I_{t-1}\right)\right] \\
& +E_{t}\left[s_{t+1}-\left(p_{t+1}-p_{t+1}^{*}\right)\right]-E_{t-1}\left[s_{t}-\left(p_{t}-p_{t}^{*}\right)\right] .
\end{aligned}
$$

In deriving equation (25) it was assumed that the expected value of a variable for period $t$, based on the information available in period $t$, equals the actual value of that variable, e.g., $E_{t} p_{t}=p_{t}$.

Equation (25) demonstrates the relation between the exchange rate and the components of the nominal rate of interest. The first bracketed term in equation 
(25) suggests that a rise in the domestic rate of inflation relative to foreign inflation is associated with a depreciation of the domestic currency (a rise in $\left.s_{t}\right)$. The second bracketed term in equation (25) suggests that a rise in the domestic real rate of interest relative to the foreign rate is associated with an appreciation of the domestic currency (a fall in $s_{t}$ ). The additional terms on the right hand side of equation (25) describe differences in expectations concerning real exchange rates. ${ }^{16}$ The different relations between the exchange rate on the one hand and the two components of the nominal interest rate on the other, is the basis for the policy prescription that is specified below.

\section{Policy Prescription}

The recommended policy prescription is based on the supposition that data from the market for foreign exchange can be used in combination with data on interest rates in order to provide the monetary authorities with useful information on money market conditions. Such information can contribute to the improved conduct of monetary policy in spite of the difficulties which stem from the constraints imposed by the openness of the economy. Accordingly, a combination of a high nominal-interest-rate differential and a depreciation of the currency, that seems to have prevailed in the U.S. during most of the 1970's may have indicated a rise in inflationary expectations. Our analysis indicates that under such circumstances an increase in the supply of money may not be desirable. On the other hand, a combination of a high nominal interest-rate differential and an appreciation of the currency that seems to have prevailed since the latter part of 1979, may indicate a rise in the demand for money. Under such circumstances accommodation by an expansionary monetary policy may not be desirable (this argument draws on Frenkel and Mussa $(1980,1981$ ) and Frenke1 (1981)). 
This prescription that is based on the relation between exchange rates and interest rates can also shed light on the recent controversy concerning the proper conduct of U.S. monetary policy in view of the high rates of interest that have prevailed since 1980 . The relatively tight monetary policy which accompanied the high nominal rate of interest in the U.S. was justified on the grounds that the high nominal rate of interest was primarily due to high inflationary expectations. As a counter argument it was argued that the prime reason for the high nominal rate of interest was the high real rate rather than inflationary expectations. Obviously, the two alternative prescriptions call for fundamentally different monetary policies. To combat inflationary expectations monetary policy had to be tight but to combat high real rates of interest a case could be made for a more relaxed monetary policy.

Here again the relation between the exchange rate and the rate of interest can provide the monetary authority with information that can be helpful in solving the "signal extraction" problem. By and large, since the latter part of 1979 , the high nominal rate of interest in the U.S. has been accompanied by an appreciation of the dollar. This suggests that since late 1979 through the present (end of 1982), the important factor underlying the evolution of the nominal rate of interest in the U.S. has been the evolution of the real rate of interest rather than inflationary expectations. Under such circumstances the U.S. monetary policy could have afforded to be more relaxed while paying even more attention to the underlying reasons for the high real interest rates.

Several factors have contributed to the rise in real interest rates. First, there have been large current and prospective budget deficits in the United States and in the rest of the world associated with large borrowing 
needs for government finance. Second, especially in the United States, the disinflation policies and monetary tightness created liquidity shortage and induced upward pressures on real rates of interest. Third, stagflation lowered the hedging quality of bonds. With a weak economy and high inflation, the real interest rate on bonds declines. For bonds to be more attractive to bondholders, they must bear a higher real yield. Fourth, high real interest rates represent a rise in the risk premium, attributable to several factors: (a) the projected rise in future budget deficits creates uncertainty about how these deficits will be financed; (b) the volatility of monetary policy since late 1979 may have induced a rise in the risk premium; and (c) the fragility of the world financial system, the sequence of banking crises, the increased perception of sovereign risk and increased sensitivity to large exposures, and the increased reluctance to extend additional credit have all contributed to the rise in the risk premium and in real interest rates. This rise in risk has been reflected in the increased spread between high- and low-quality bonds. Fifth, it has been argued that changes in the laws dealing with the treatment of depreciation and in those dealing with bankruptcies have also contributed to the rise in real interest rates.

This perspective suggests that monetary policy can use the information provided by the foreign exchange market to identify the source of variations in nominal rates of interest. Thus, the external sector, while imposing severe constraints on monetary policy, is also providing it with useful information. 
V. THE ROLE OF THE IMF AND INSTITUTIONAL REFORM

The unprecedented heights of the real rates of interest in the United States and in the rest of the world coupled with world recession and with the debt explosion of developing countries, resulted in severe difficulties in world credit markets and have served to focus attention on the provision of international liquidity, credit, as well as on the role of the lender of last resort.

The responsibility of the lender of last resort is to step in and lend (possibly at penalty rates) so as to ensure that credit markets do not dry. How is this responsibility related to the IMF? Generally, the task of the lender of last resort for domestic banks must be assumed by each central bank, keeping in mind, of course, that its purpose is to protect depositors and alleviate a state of panic without necessarily protecting stock holders. With respect to the role and size of the IMF, it is relevant to note that the Fund's lending operations are secondary to its main responsibility of maintaining the smooth operation of the international payment mechanism. The instrument which the Fund has at its disposal is the various conditionality measures which it uses as criteria for lending. The application of the Fund's conditionality measures may provide a signal to potential lenders that the risk of lending to the countries in question has been reduced and, thereby, may open up the otherwise closed credit lines. Of course, this operation may not be as smooth in the short run during which the Fund itself may need to step in and prevent the drying up of credit lines to countries which are seriously illiquid. For such cases there is indeed a serious argument for an increase in the IMF financial 
resources, and even possibly for the institution of some collaborative arrangements between the IMF and the major commercial banks concerning the proper provision of credits. If such resources are not provided, countries might be tempted to regain monetary control through the imposition of protective measures that aim at insulation.

Indeed, world recession and rising unemployment have led to the dangerous growth of protectionism and of inward-looking policies. These policies have reflected themselves in the imposition of barriers to the international free flow of goods and capital as well as in attempts to manipulate exchange rates. These measures were introduced as countries attempted to diminish the constraints that the openness of the economy imposes on the effectiveness of policies.

In principle, the legal framework necessary for the prevention of such measures is partially in place. The principles and procedures for IMF surveillance of exchange-rate policies should contribute to diminishing the number of incidents of exchange-rate manipulation which are aimed at preventing effective balance of payments adjustment. Likewise, the rules of GATT are intended to reduce the number of incidents of policy induced trade barriers. Consequently, it is extremely important that such international institutions be strengthened.

There is, however, a need for an important institutional reform that would provide for a key addition to the GATT and to IMF surveillance. The GATT deals with interventions that affect the trade account of the balance of payments, and IMF surveillance deals with interventions that affect exchange rates. Under a clean float, however, any policy that affects the current account of the balance of payments must also be fully reflected in the capital account, and vice versa. It follows that capital-market interventions may have protectionist 
trade effects as severe as those resulting from the imposition of more conventional trade barriers. ${ }^{17}$ A third agreement is therefore required to deal directly with interventions that affect the capital account of the balance of payments. Without a capital-account analogue to the GATT--which maybe called GACF--(for General Agreement on Capital Flows)--or without a proper extension of the principles of surveillance to the broader range of monetary policies and capital market interventions, efforts to reduce protectionism maybe futile as countries attempt to regain monetary control through the imposition of barriers to the free flow of capital. 
FOOTNOTES

${ }^{1}$ An additional variable which in principle should have been included in the list of the determinants of reserve holdings is the opportunity cost of holding reserves. In practice, a large fraction of international reserves is held in the form of short term interest-bearing assets and thus, the opportunity cost is the difference between the alternative yield and the rate of return on reserves. Previous studies faced serious difficulties in estimating this cost. Clark (1970a) decided to exclude this variable from his estimation. Heller (1966) assumed that the cost was the same for all countries ( 5 percent). Kenen and Yudin (1965) used income per capita as a proxy, and found that it had the "wrong" sign and was not significant. Kelly (1970) used, in addition to per capita income, the value of foreign assets and liabilities as proxies, but found that in all cases the latter appeared with the "wrong" sign while in some cases the former had the "wrong" sign. Courchene and Youssef (1967) used the long-term interest rate as a proxy, and found that in five out of nine cases its coefficient was not significantly negative. All these attempts taken together provided the rationale for not including this variable in the estimating equations. For an incorporation of the rate of interest into a stochastic framework see Frenke1 and Jovanovic (1981).

2 From the list of countries for which data were available, two countries--Canada and the United States--were excluded from the analysis. Canada was excluded since it had a flexible exchange-rate system during most 
of the period for which the variability measure was calculated. Since the discussion focuses on the behavior of countries as demanders of reserves, the exclusion of the United States as the main supplier seems justified.

${ }^{3}$ As is indicated in Appendix II, in order to obtain a variability measure that is free of scale, the standard deviation of the trend-adjusted changes in reserves was divided by the value of imports.

${ }^{4}$ It is also noteworthy that in most cases the income elasticity of reserve holdings is about unity and is estimated with great precision. This suggests that countries' size is an important determinant of reserve holdings. The unitary elasticity suggests that the dependence of the reserves/income ratio on the measures of variability and openness is similar to the dependence of reserve holdings on these measures.

5 For this and other methods of analyzing switching regressions see Goldfeld and Quandt (1976, Chs. 1, 4). The same procedure was used in Frenkel (1978). The application in the present paper uses an extended data base and, more importantly, employs a specification of the demand for reserves in which reserves are measured in real terms and the variability measure is free of scale.

${ }^{6}$ It should be noted that the application of this method to the problem at hand is not without conceptual difficulties since it requires differentiating the likelihood function with respect to $t^{*}$. It should also be noted that the analysis assumes that the structural change has taken place at a given point in time. An alternative approach would allow for a gradual evolution, and would estimate regression equations with variable coefficients. For references and discussion of the properties of the distribution of $-2 \ln \phi$ see Goldfeld and Quandt (1976, Ch. 1). 
${ }^{7}$ The subsequent discussion builds on Frenkel and Hakkio (1980). ${ }^{8}$ Setting $\Sigma \lambda_{t}=0$ does not imply, of course, that we ignore the time specific factor since it is implicit in the estimates of $\hat{\mu}_{i}$ and $\hat{\beta}_{\text {GLS }}$.

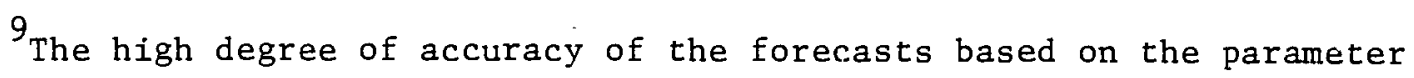
estimates from 1963-72 is especially remarkable in view of the significant changes in the roles played by gross and net measures of reserves and in view of the different practices concerning the valuations of gold. On the role of gold and on estimates of the demand for non-gold reserves see von Furstenberg (1982).

${ }^{10}$ For a study reporting a relatively high speed of adjustment see, however, Edwards (1980).

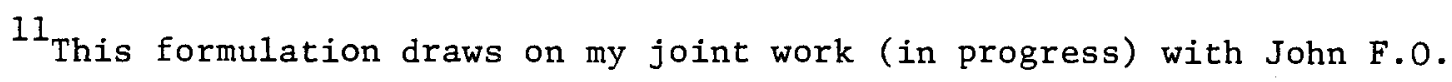
Bilson. For a recent attempt to integrate monetary and reserves considerations see Levi (1983).

12 For analyses of the effects of the move to floating exchange rates on the demand for and the optimal provision of international reserves see Grubel (1976), Makin (1974) and Williamson (1976).

13 The subsequent analysis draws on Frenkel (1983). My assignment for this conference has been to deal with monetary control; therefore, the subsequent discussion focuses on the role of monetary policy. This focus should not be interpreted to argue that fiscal policy considerations are of a lesser importance. For an analysis of the constraints on fiscal policies see Frenkel and Mussa (1981). 
${ }^{14}$ While these are the general characteristics of the adjustment process, the details of the precise path are somewhat more complicated since the expected transitional changes in the exchange rates will alter transitorily the rate of interest. Along the path between $E$ and $D$ the domestic currency appreciates and, if this appreciation is expected, the domestic rate of interest is below the world rate due to interest arbitrage. Therefore, during the transition period the desired ratio of money to equities will exceed the one described in Figure 1. The new equilibrium is reached at point $A$ when the exchange rate reaches its new level, and when the domestic and the foreign rates of interest are equalized.

${ }^{15}$ The importance of the degree of capitalization and marketability of claims to future income streams were analysed in the context of a closed economy by Metzler (1951) and Mundell (1960).

${ }^{16}$ The distinction between the roles of the real and the nominal rates of interest has been emphasized by Frankel (1979). The framework underlying equation (25) is based on Isard (1983). See also the discussion in Edwards (1983). The interpretation of the empirical record in terms of the three bracketed terms in equation (25) should be only viewed as suggestive since in practice these terms represent endogenous variables that also need to be explained along with the exchange rate in terms of the exogenous variables.

17 While the protectionist impacts of capital account interventions may be as severe as those arising from conventional trade barriers, there are important differences between the two forms of protection. Capital account intervention tends to result in a closer synchronization between expenditures and income and, thereby, smaller current account imbalances. Trade intervention might also affect the size of the current account but its pronounced effects may be reflected in the commodity composition of trade. 
APPENDIX I

List of Countries and Definitions of Variables

List of Countries $^{1}$

\begin{tabular}{lll} 
Developed Countries & \multicolumn{2}{c}{ Less-Developed Countries } \\
United Kingdom & Argentina & Jamaica \\
Austria & Brazil & Israel \\
Belgium & Chile & Jordan \\
Denmark & Columbia & Egypt \\
France & Costa Rica & Burma \\
Germany & Dom. Republic & Sri Lanka \\
Italy & & China \\
Netherlands & Ecuador & India \\
Norway & El Saivador & Korea \\
Sweden & Guatemala & Malaysia \\
Switzerland & Honduras & Pakistan \\
Japan & Mexico & Philippines \\
Finland & Nicaragua & Thailand \\
Greece & Panama & Ghana \\
Iceland & Paraguay & Sudan \\
Ireland & Peru & Tunisia \\
Portugal & Venezuela & \\
Spatn & & \\
Turkey & & \\
Australia & & \\
New Zealand & & \\
South Africa & & \\
\hline
\end{tabular}

${ }^{1}$ Classification based on the International Monetary Fund. 
Definitions and Variables

All data sources are from the IFS tape obtained from the International Monetary Fund (the December 1979 version for the developed countries, and the May 1979 version for the less-developed countries), except as indicated. Data for the developed countries have been updated to the August 1980 IFS book.

$R$ - International Reserves are measured in real end-of-period $10^{6} \mathrm{U.S}$. dollars, using the U.S. GNP deflator P. Reserves are defined as the sum of gold, SDRs, foreign exchange and reserve position at the Fund. When reserves are reported in local currency, they were converted to U.S. dollars using the end-of-period exchange rate.

IM - Imports are measured as cif in $10^{9} \mathrm{U} . \mathrm{S}$. dollars. When reported in local currency, they were converted to U.S. dollars using the period average exchange rate.

Y - Real income. GNP and GDP are reported in local currency units. These figures were converted to real $10^{9} \mathrm{U} . \mathrm{S}$. dollars using the period average exchange rate and the U.S. GNP deflator, P.

m - The average propensity to import was defined as the ratio of imports to GNP. When the latter was unavailable, GDP was used instead.

$\sigma$ - The variability measure. To calculate the value of $\sigma_{T}^{2}$ for year $T$ for a given country, the following regression was first run with reserves in nominal terms:

$$
R_{t}=a+\beta_{T-1} t+u \text { over } t=T-15, \ldots, T-1
$$

(except for 1963 for which, due to lack of data, $\tilde{\sigma}_{T}^{2}$ is based on the previous 14 observations). Then using the estimated trend $\hat{B}_{T-I^{\prime}} \delta_{T}^{2}$
was defined as

$$
\tilde{\sigma}_{T}^{2}=\sum_{t=T-14}^{T-1}\left(R_{t}-R_{t-1}-\hat{\beta}_{T-1}\right)^{2} / 14 .
$$

Thus $\tilde{\sigma}_{T}^{2}$ is defined as the variance of the trend-adjusted changes in the stock of international reserves. A plot of the time-series of reserves revealed that the assumption of a linear trend seems more appropriate than that of an exponential trend. In order to obtain a measure of variability that is free of scale, our variability measure for period $T$ is the ratio of the standard error of the trend-adjusted changes in reserves to the value of imports. Thus $\sigma_{T}=J_{T} / M_{T}$. 
P - Prices are measured by the U.S. GNP deflator from the IFS publication of Annual Data, May 1976. They are updated to the August 1980 IFS book. 
REF ERENCES

Allen, Polly R. and Peter B. Kenen. Asset Markets, Exchange Rates and Economic Integration (Cambridge: Cambridge University Press, 1980). Archibald, G.C. and J. Richmond, "On the Theory of Foreign Exchange Reserve Requirements," The Review of Economic Studies 38 (April 1971), pp. $245-263$.

Balestra, Paul and Marc Nerlove, "Pooling Cross Section and Time Series Data in the Estimation of a Dynamic Model: The Demand for Natural Gas," Econometrica, 34 (1966), pp. 585-612.

Bilson, John F.O. and Jacob A. Frenkel (1979a), "Dynamic Adjustment and the Demand for International Reserves," (NBER working paper No. 407, November 1979).

(1979b), "International Reserves: Adjustment Dynamics," Economics Letters (Amsterdam), Vo1. 4 (June 1979), pp. $267-70$.

Branson, William H., "Assets Markets and Relative Prices in Exchange Rate Determination," Sozialwissenschaftliche Annalen, No. 1 (1979) pp. 69-89.

Claassen, Emil M., "The Optimizing Approach to the Demand for International Reserves," Weltwirtschaftliches Archiv 3 (1974) pp. 353-398.

Clark, Peter B. (1970a), "Demand for International Reserves: A Cross-Country Analysis," Canadian Journal of Economics 3 (November 1970a) pp. 577-594. (1970b), "Optimum International Reserves and the Speed of Adjustment," Journal of Political Economy, 78(2) (1970b), pp. 356-76. 
Clower, Robert and Richard Lipsey, "The Present State of International Liquidity Theory," American Economic Review 57 (May 1968), pp . 586-594. Cohen, Benjamin J. "International Reserves and Liquidity: A Survey," in International Trade and Finance, ed. by Peter B. Kenen (Cambridge: Cambridge University Press, 1975), PP. 411-451.

Courchene, Thomas J. and G.M. Youseff, "The Demand for International Reserves," Journal of Political Economy 75(4) Part I (August 1967), pp. 404-13. Cumby, Robert E. "Special Drawing Rights and Plans for Reform of the International Monetary System: A Survey," International Monetary Fund Working Paper, 1982.

Edwards, Sebastian (1980), "A Note on the Dynamic Adjustment of the Demand for International Reserves by LDC's," Economics Letters, Vol. 5 (1980), PP. 71-74.

(1983), "Comments on 'An Accounting Framework and Some Issues for Modelling How Exchange Rates Respond to the News'," in Exchange Rates and International Macroeconomics, Edited by Jacob A. Frenkel (Chicago: University of Chicago Press, 1983), forthcoming.

Flanders, M. June "The Demand for International Reserves," Princeton Studies in International Finance 27 (1971), pp. 1-50.

Frenkel, Jacob A. (1974a) "Openness and the Demand for International Reserves," in National Monetary Policies and the International Financial System, ed. by R.Z. Aliber (Chicago: University of Chicago Press, 1974), Pp. 289-98.

(1974b) "The Demand for International Reserves by Developed and LessDeveloped Countries," Economica 41, 161 (February 1974), pp. 14-24. 
Frenkel, Jacob A. (1978) "International Reserves: Pegged Exchange Rates and Managed Float," in Economic Policies in Open Economies, ed. by $\mathrm{K}$. Brunner and A.H. Meltzer (Carnegie-Rochester Conference Series on Public Policy, Vol. 9, supplementary Series to the Journal of Monetary Economics, July 1978).

(1981) "Flexible Exchange Rates, Prices and the Role of 'News': Lessons from the 1970's," Journal of Political Economy 89 (4) (August 1981), pp. 665-705.

(1983) "Monetary Policy: Domestic Targets and International Constraints," American Economic Review 73 (2) (May 1983), forthcoming. and Joshua Aizenman (1982), "Aspects of the Optimal Management of Exchange Rates", Journal of International Economics 13 (November 1982) pp. 231-56. and Craig S. Hakkio (1980), "Country-Specific and Time-Specific Factors in the Demand for International Reserves," Economics Letters, Vol. 5 (1980), pp. 75-80. and Boyan Jovanovic (1981), "Optimal International Reserves: A Stochastic Framework," The Economic Journal Vol. 91 (June 1981) pp. 507-14.

and Michael L. Mussa (1980) "The Efficiency of Foreign Exchange Markets and Measures of Turbulence," American Economic Review Vol. 70 (May 1980), pp. 374-81. and Michael L. Mussa (1981), "Monetary and Fiscal Policies in an Open-Economy," American Economic Review Vol. 71 (May 1981), pp. 253-58. and Carlos A. Rodriguez (1975), "Portfolio Equilibrium and the Balance of Payments: A Monetary Approach," American Economic Review Vo1. 65 (September 1975), pp. 674-88. 
Goldfeld, Stephen M. and Richard E. Quandt, eds. Studies in Nonlinear Estimation (Cambridge: Ballinger, 1976).

Grubel, Herbert G. (1971) "The Demand for International Reserves: A Critical Review of the Literature," Journal of Economic Literature 9 (December 1971), pp. 1148-1166. (1976) "The Optimum Supply of International Reserves in a World of Managed Floating," Paper presented at the Marcus Fleming Memorial Conference on The New International Monetary System, Washington, D.C., (November 1976).

Gujarti, Damodar "The Use of Dummy Variables in Testing for Equality Between Sets of Coefficients in Linear Regressions: A Generalization," The American Statistician (December 1970), pp. 18-22.

Heller, H. Robert (1966), "Optimal International Reserves," Economic Journal 76 (June 1966), pp. 296-311. and Mohsin S. Kahn (1978) "The Demand for International Reserves Under Fixed and Floating Exchange Rates," International Monetary Fund Staff Papers 25,4 (December 1978), pp. 623-49.

Hipple, F. Steb, "The Disturbances Approach to the Demand for International Reserves," Princeton Studies in International Finance 35 (May 1974). International Monetary Fund, International Reserves: Needs and Availability (Washington: International Monetary Fund, 1970). Isard, Peter "An Accounting Framework and Some Issues for Modelling How Exchange Rates Respond to the News," in Exchange Rates and International Macroeconomics, ed. by Jacob A. Frenkel (Chicago: University of Chicago Press, 1983) forthcoming. 
Iyoha, Milton A. "Demand for International Reserves in Less Developed Countries: A Distributed Lag Specification," The Review of Economics and Statistics 58, 3 (August 1976), pp. 351-55.

Kelly, Michael G. "The Demand for International Reserves," American Economic Review 60 (September 1970), pp. 655-667.

Kenen, Peter B. and Elinor B. Yudin, "The Demand for International Reserves," Review of Economics and Statistics 47 (August 1965), pp. 242-250.

Levi, Victor (1983), "Demand for International Reserves and Exchange-Rate Intervention Policy in an Adjustable-Peg Economy," Journal of Monetary Economics 11, 1 (January 1983), pp. 89-101.

Makin, John H. "Exchange Rate Flexibility and the Demand for International Reserves," Weltwirtschaftliches Archiv 110,2 (1974), Pp . 229-43. Metzler, Lloyd A. "Wealth, Savings and the Rate of Interest," Journal of Political Economy 59, 2, (April 1951), pp. 93-116.

Munde11, Robert A. (1960), "The Public Debt, Corporate Income Taxes and the Rate of Interest," Journal of Political Economy 68,2 (December 1960), Pि. 622-26.

(1968), International Economics (New York: MacMillan, 1968).

Mussa, Michael L. (1976), "The Exchange Rate, the Balance of Payments and Monetary and Fiscal Policy Under a Regime of Controlled Floating," Scandinavian Journal of Economics 78, 2 (May 1976), pp. 229-48. Reprinted in Frenkel, J.A. and H.G. Johnson (eds.) The Economics of Exchange Rates: Selected Studies (Reading: Addison-Wesley, 1978). (1979), "Empirical Regularities in the Behavior of Exchange Rates and Theories of the Foreign Exchange Market," Vol. 11 of the Carnegie-Rochester Conference Series on Public Policy, a supplementary series to the Journal of Monetary Economics (1979), pp. 9-57. 
Mussa, Michael L. (1981), "The Role of Official Intervention," Group of Thirty, New York, Occasional Papers, No. 6, 1981.

Obstfeld, Maurice "Exchange Rates, Inflation and the Sterilization Problem: Germany, 1975-1981," European Economic Review (1983) forthcoming. Quandt, Richard E. (1958) "The Estimation of the Parameters of a Linear Regression System Obeying Two Separate Regimes," Journal of the American Statistical Association 53 (September 1958), pp . 873-80, 1960, "Tests of the Hypothesis that a Linear Regression System Obeys Two Separate Regimes," Journal of the American Statistical Association 53 (September 1958), PP. 873-60.

Suss, Esther, C. "A Note on Reserve Use Under Alternative Exchange Rate Regimes," International Monetary Fund Staff Papers 23, 2 (July 1976) pp. 387-94.

Theil, Henry Economic Forecasts and Policy 2nd edition (North-Holland Publishing Co., Amsterdam, 1961)

von Furstenberg, George M. "New Estimates of the Demand for Non-Gold Reserves Under Floating," Journal of Internationa1 Money and Finance (London, Vol. 1, April 1982), Pp. 81-95.

Wallich, Henry C. 'Exchange-Market Intervention: Issues and Views,' The Jcurnal of Cormerce (August 12-13, 1982). Williamsoñ, John (1973), "International Liquidity: A Survey," Economic Journal 83 (September 1973), PP • 685-746. (1976), "Generalized Floating and the Reserve Needs of Developing Countries," in The Internationa1 Monetary System and Developing Nations, ed. by D.M. Leipziger (Washington, D.C.: Agency for International Development, 1976), Pp. 75-86. 